\title{
New Substituted Benzoylthiourea Derivatives: From Design to Antimicrobial Applications
}

\author{
Carmen Limban ${ }^{1}$, Mariana Carmen Chifiriuc ${ }^{2, *}$, Miron Teodor Caproiu ${ }^{3}$, Florea Dumitrascu ${ }^{3}$, \\ Marilena Ferbinteanu ${ }^{4}$, Lucia Pintilie 5 ${ }^{(0)}$, Amalia Stefaniu ${ }^{5}$, Ilinca Margareta Vlad ${ }^{1}$, \\ Coralia Bleotu $^{6}{ }^{(D}$, Luminita Gabriela Marutescu ${ }^{2}$ and Diana Camelia Nuta ${ }^{1}$ \\ 1 Department of Pharmaceutical Chemistry, “Carol Davila” University of Medicine and Pharmacy, \\ 020956 Bucharest, Romania; carmen.limban@umfcd.ro (C.L.); ilinca.vlad@drd.umfcd.ro (I.M.V.); \\ diana.nuta@umfcd.ro (D.C.N.) \\ 2 Department of Microbiology, Faculty of Biology \& Research Institute of the University of Bucharest (ICUB), \\ University of Bucharest, 060101 Bucharest, Romania; lumi.marutescu@gmail.com \\ 3 The Organic Chemistry Center of Romanian Academy “C. D. Neniţescu”, 060023 Bucharest, Romania; \\ dorucaproiu@gmail.com (M.T.C.); fdumitra@yahoo.com (F.D.) \\ 4 Inorganic Chemistry Department, Faculty of Chemistry, University of Bucharest, 020462 Bucharest, Romania; \\ marilena.cimpoesu@g.unibuc.ro \\ 5 National Institute of Chemical-Pharmaceutical Research \& Development, 031299 Bucharest, Romania; \\ lucia.pintilie@gmail.com (L.P.); astefaniu@gmail.com (A.S.) \\ 6 Stefan S. Nicolau Institute of Virology, Mihai Bravu 285, Bucharest, 030304, Romania; cbleotu@yahoo.com \\ * Correspondence: carmen.chifiriuc@bio.unibuc.ro
}

Received: 21 February 2020; Accepted: 20 March 2020; Published: 25 March 2020

\begin{abstract}
The increasing threat of antimicrobial resistance to all currently available therapeutic agents has urged the development of novel antimicrobials. In this context, a series of new benzoylthiourea derivatives substituted with one or more fluorine atoms and with the trifluoromethyl group have been tested, synthesized, and characterized by IR, NMR, CHNS and crystal X-ray diffraction. The molecular docking has provided information regarding the binding affinity and the orientation of the new compounds to Escherichia coli DNA gyrase B. The docking score predicted the antimicrobial activity of the studied compounds, especially against $E$. coli, which was further demonstrated experimentally against planktonic and biofilm embedded bacterial and fungal cells. The compounds bearing one fluorine atom on the phenyl ring have shown the best antibacterial effect, while those with three fluorine atoms exhibited the most intensive antifungal activity. All tested compounds exhibited antibiofilm activity, correlated with the trifluoromethyl substituent, most favorable in para position.
\end{abstract}

Keywords: benzoylthiourea derivatives; antimicrobial; antibiofilm; X-ray; in silico

\section{Introduction}

In the last decades, thiourea derivatives have received considerable attention owing to their effective biological activities, including the antibacterial [1-6], antitubercular [7,8], antimalarial [9-11], antileishmanial [12], antifungal [13-16], or antiviral effects [17-23].

Thiourea substitution in anacardic acids' C-8 alkyl chain provided anti-Escherichia coli, Pseudomonas aeruginosa, Staphylococcus aureus, and Streptococcus pyogenes activity. Methyl 2-methoxy-6-\{8-\{3-[3-(trifluoromethyl)phenyl]thioureido\}octyl\}benzoate exhibited a biological activity similar to the standard antibiotic ampicillin [24]. On the contrary, $p$-(3-trifluoromethyl-5substituted-pyrazol-1-yl)benzenesulfonylthiourea derivatives have been less effective than ampicillin and griseofulvin against S. aureus, E. coli, Aspergillus niger and Candida albicans [25]. Thereby, the 
(E)-N-[4-(benzamidomethylenamino)phenylcarbamothioyl]benzamide exhibited a good antibacterial activity [4].

The N-[(arylamino)thioxomethyl]-3,5-dichlorobenzo[b]thiophene-2-carboxamide displayed in vitro both antibacterial (i.e., against E. coli, Proteus vulgaris, Bacillus megaterium, S. aureus) and antifungal (i.e., against $A$. niger) activities [5]. Also, a series of diversely substituted $N$ - $p$-methylbenzoyl- $N^{\prime}$ thiourea derivatives, such as $N$-(4-methylbenzoyl)- $N^{\prime}$-(4-chloro2-nitrophenyl)thiourea and $N$-(4-methylbenzoyl)- $N^{\prime}$-(4-methylphenyl)thiourea have been proven to exhibit antibacterial and antifungal activities [6] (Figure 1).

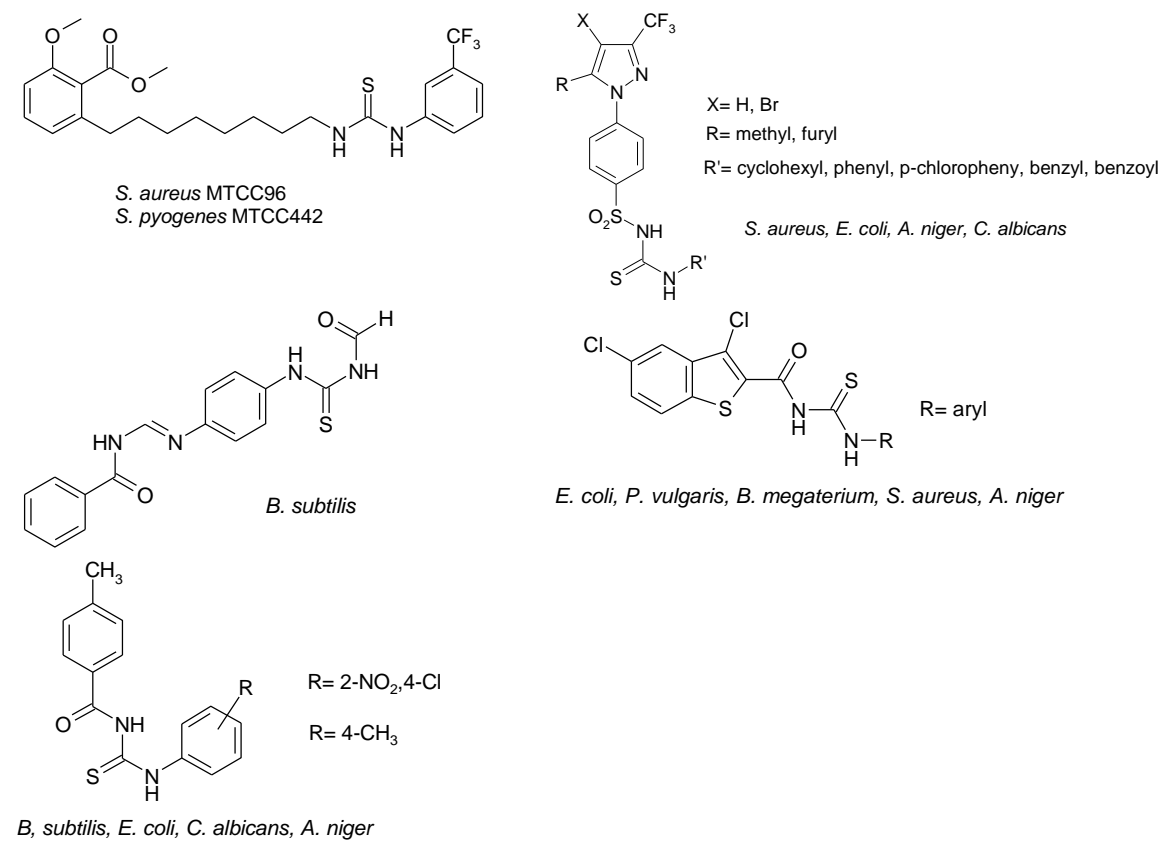

Figure 1. Antimicrobial thiourea derivatives.

Thiophanate and thiophanate methyl are thiourea-based fungicides largely used on different fruits and vegetable crops. The 1,3-disubstituted aliphatic and aromatic symmetrical and unsymmetrical thioureas proved to be effective against Pyricularia oryzae and Drechslera oryzae phytopathogens [26], while $N$-(o-fluorophenoxyacetyl)thiourea derivatives exhibited herbicidal activity against Amaranthus retroflexus L. [27].

In the last 15 years the fluoro-derivatives class has flourished. In 2018 FDA approved 17 new molecules, among which fostamatinib, baloxavir, marboxil, doravirine, ivosidenib, and apalutamide [28]. The isosteric modification, consisting of replacing hydrogen with fluorine, modifies the steric and electronic properties of the resulting molecules, affecting their metabolic transformations because of the relative stability given by the C-F energy bond $(485.7 \mathrm{~kJ} / \mathrm{mol})$ [29]. The presence of the fluorine atom modulates the pharmacodynamic and pharmacokinetic properties [25]. Drug fluorination is commonly used to modulate pKa values, to enhance membrane permeation, and to increase liposolubility and, thus, their in vivo absorption and transport $[30,31]$. The thiourea skeleton favors other chemical modulations (e.g., incorporation of fluorine), these derivatives being thus promising candidates, both as active molecules and ligands. For instance, the fluoroquinolone derivatives having thioureido moiety and piperazin-1-yl groups have shown a significant improvement of the activity against Gram-positive (S. aureus, B. subtilis) and Gram-negative (E. coli, P. aeruginosa) bacterial strains [32]. The 2-(6'-fluorobenzothiazol-2'-ylamino)-4,6-(disubstituted thioureido)-1,3-pyrimidine derivatives and the 1-(isomeric fluorobenzoyl)-3-(isomeric fluorophenyl)thiourea compounds have shown inhibitory activity against the above-mentioned four species, correlated with the presence of 
nitro groups and with the presence and position of fluorine substituent on aroyl and aryl rings [33,34]. The last ones exhibited a better antifungal activity against Rhizopus oryzae, Aspergillus terreus, Fusarium oxysporum, A. niger, and A. fumigatus, probably due to the presence of fluorine, which increased their lipophilicity, penetration rate, and intracellular transport to the microbial target. An improved receptor binding could be achieved due to the higher polarizability assured by the C-F bond [34].

On the other hand, the trifluoromethyl group is an important substituent in many drugs or agrochemical compounds because it increases the lipophilicity and metabolic stability [29]. Therefore, a number of synthesis methods for such compounds have been developed [35] so that it can be expected that in the future a lot of new molecules with biological activity from the class of trifluoromethyl derivatives will be developed [36].

Furthermore, the synthesis methods of organofluorine chemicals are intensively studied [37] due to their various applications in medicine, chemistry, and agriculture. Organofluorine compounds are used for treating bacterial (e.g., fluoroquinolones), fungal (fluconazole, flucytosine), and viral (e.g., clevudine for hepatitis B, efavirenz for HIV infection) infections, malaria (mefloquine), cancer (e.g., 5-fluorouracil, a thymidylate synthase inhibitor, floxuridine, an antimetabolite in the treatment of colorectal cancer, bicalutamide, a nonsteroidal anti-androgen, flutamide with anti-androgen properties), diabetes (tolrestat, an aldose reductase inhibitor used in diabetic complications, sitagliptin, a dipeptidyl peptidase-4 inhibitor), superficial or systemic hypercholesterolemia (atorvastatin, an inhibitor of 3-hydroxy-3-methyl-glutaryl-CoA reductase, torcetrapib, a cholesterylester transfer protein inhibitor), asthma and allergic rhinitis (fluticasone propionate), glaucoma (travoprost, tafluprost), and depression (e.g., fluoxetine, a selective serotonin reuptake inhibitor), as well as for maintenance of general anesthesia (desflurane).

The common isotope of fluorine $\left({ }^{19} \mathrm{~F}\right)$ is the favorite heteroatom for incorporation into drugs [26], while the isotope $\left({ }^{18} \mathrm{~F}\right)$ is used for radiolabelling of some ligands used in HD PET imaging for Huntington disease diagnosis [38]. Recently, fluorodopa (FDOPATM), the fluorine-18 isotopologue of L-DOPA, was approved as a radiotracer in PET for the visualization of nerve cells in patients with symptoms of Parkinson disease [39].

Presently, the emergence of antimicrobial resistance in human, animal, and plant pathogens, correlated with the unavailability of newer drugs challenges the efficiency of current antimicrobial agents [40]. Therefore, comprehensive and multidisciplinary efforts across human medicine, veterinary, agricultural, and environmental sectors are needed to reduce this global threat by investigating the mechanisms of resistance, improving antimicrobial stewardship, and developing antimicrobial agents [41-43].

Our aim was to exploit the multiple advantages of 2-((4-ethylphenoxy)methyl)- $\mathrm{N}$-(fluoro/trifluorosubstituted phenylcarbamothioyl)benzamides to obtain potent antibacterial and antifungal agents, potentially useful for both clinical and agricultural sectors.

\section{Results}

As a continuation of our previous research [44,45], we have synthesized new compounds bearing the fluorine atom/trifluoromethyl group and the thiourea moiety (i.e., 2-((4-ethylphenoxy)methyl)- $\mathrm{N}$-(fluoro/trifluoromethyl-phenylcarbamothioyl)benzamides), and evaluated their antimicrobial activity.

\subsection{Chemistry}

The new compounds, $5 \mathbf{a}-\mathbf{g}$, were obtained with good yields using the synthesis route presented in Scheme 1. 

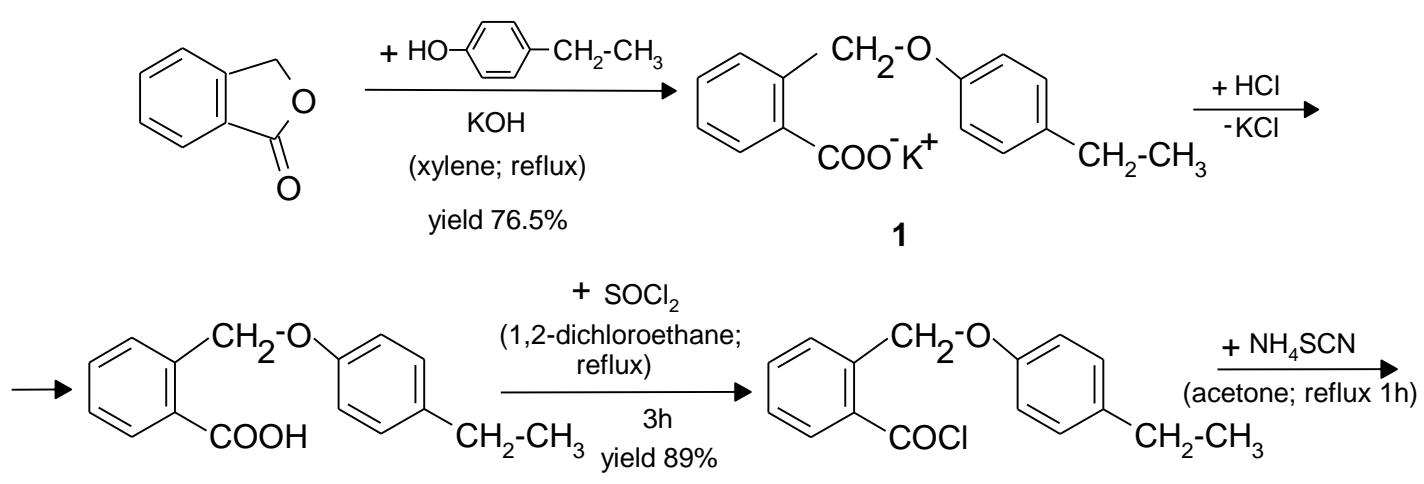

2

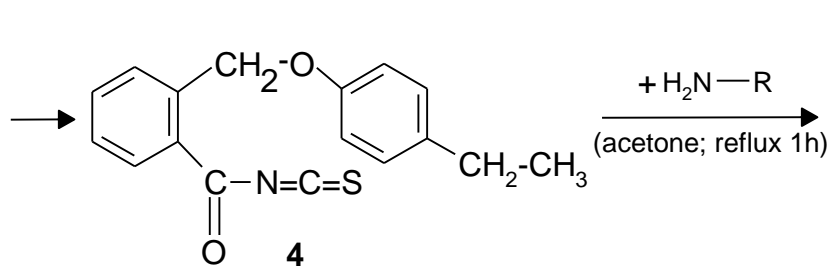<smiles>Fc1cccc(F)c1</smiles>

$5 a$<smiles>Fc1ccc(F)c(F)c1F</smiles>

$5 b$

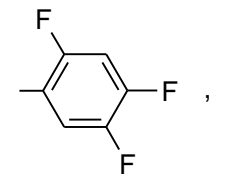

$5 c$<smiles>[R]NC(=S)NC(=O)c1ccccc1COc1ccc(CC)cc1</smiles>

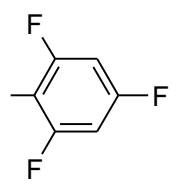

$5 d$<smiles>Fc1cc(I)cc(F)c1F</smiles>

$5 e$

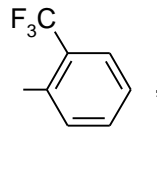

$5 f$<smiles>FC(F)(F)c1ccc(I)cc1</smiles>

$5 g$

Scheme 1. Synthesis of the new derivatives $(5 \mathbf{a}-\mathbf{g})$.

Phthalide was refluxed with potassium $p$-ethylphenoxide in xylene, resulting in the potassium salt of 2-(4-ethylphenoxymethyl)benzoic acid (1), which was separated from xylene due to its solubility in the $10 \%$ aqueous potassium hydroxide solution. The 2-(4-ethylphenoxymethyl)benzoic acid (2) was precipitated using $10 \% \mathrm{HCl}$ solution. The 2-(4-ethylphenoxymethyl)benzoyl chloride (3) was prepared by refluxing acid 2 with thionyl chloride, in anhydrous 1,2-dichlorethane.

The reaction between compound 3 with ammonium thiocyanate in dry acetone resulted in in situ 2-(4-ethylphenoxymethyl)benzoyl isothiocyanate (4). The appropriate primary aromatic amines were directly added to the reaction mixture, in dry acetone, resulting in new derivatives 5a-g.

The obtained compounds were solid, white, or light-yellow crystals, exhibiting solubility in chloroform and acetone at room temperature, soluble in lower alcohols, benzene, toluene, and xylene after heating and insoluble in water.

The melting point, elemental analysis, infrared (IR), and nuclear magnetic resonance (NMR) spectral studies were used for the characterization and structure confirmation of the new compounds.

In the IR spectra, the stretching bands due to $v \mathrm{~N}-\mathrm{H}$ of the amide group can be found to the highest values of the wave numbers. These were sharp peaks with a medium intensity occurring in the region $3401 \mathrm{~cm}^{-1}$. The thioamide group showed a less intense stretching band at 3155-3183 $\mathrm{cm}^{-1}$ and, with a high probability, the band located at $1374-1392 \mathrm{~cm}^{-1}$ can be attributed to the thioamide group. For the observed antisymmetric stretching vibrations, methyl and methylene groups gave saturated $v$ C-H stretching bands at about $2959-2970 \mathrm{~cm}^{-1}$ and $2912-2933 \mathrm{~cm}^{-1}$, respectively; These bands are typical for aromatic compounds containing saturated carbons. A medium or intense sharp stretching band, shown in the IR spectrum of these compounds in the region $1676-1695 \mathrm{~cm}^{-1}$ is due 
to the $v \mathrm{C}=\mathrm{O}$ vibrations. The $v \mathrm{C}=\mathrm{O}$ band was lower than that observed with the ordinary carbonyl absorption $\left(1730 \mathrm{~cm}^{-1}\right)$. This low frequency value can be explained as a result of conjugated resonance with the phenyl ring and the formation of intramolecular hydrogen bonding with N-H. Near to this peak lies the intense band of $\delta \mathrm{N}-\mathrm{H}$, with a maximum at $1506-1514 \mathrm{~cm}^{-1}$, which overlaps the aromatic core vibrations. These compounds also show a typical alkyl-aryl ether at $1237-1256 \mathrm{~cm}^{-1}$ for the antisymmetric vibration, and $1013-1045 \mathrm{~cm}^{-1}$ for the symmetric one. The presence of fluorine in the new compounds is proven by the stretching bands situated at $1013-1079 \mathrm{~cm}^{-1}$.

The structure of the new compounds was also confirmed by the NMR spectra. The new compounds were dissolved in DMSO-d6 (hexadeuterio-dimethyl sulfoxide) and the chemical shifts' values, expressed in parts per million (ppm), were referenced downfield to tetramethylsilane for ${ }^{1} \mathrm{H}-\mathrm{NMR}$ and ${ }^{13} \mathrm{C}-\mathrm{NMR}$ and upfield to trichloro-fluoro-methane for ${ }^{19} \mathrm{~F}-\mathrm{NMR}$ and the constants $(J)$ values in Hertz. The chemical shifts for hydrogen and carbon atoms were established also by GCOSY, GHMBC, GHSQC experiments. The ${ }^{1} \mathrm{H}-\mathrm{NMR}$ data were reported in the following order: Chemical shifts, multiplicity, coupling constants, number of protons, and signal/atom attribution. Spin multiplets were given as s (singlet), d (doublet), t (triplet), q (quartet), m (multiplet), dd (double doublet), dt (double triplet), dq (double quartet), ddd (doublet of a double doublet), td (triple doublet), tdd (triplet of a double doublet), and br (broad) signal. The ${ }^{13} \mathrm{C}-\mathrm{NMR}$ data were reported in the following order: chemical shifts, coupling constants in some cases, and signal/atom attribution ((Cq) quaternary carbon). The chemical shift of N-H protons was found in the range of $\delta 12.14-12.59$ ppm for hydrogen bonds, and other protons of the N-H group were found in the range of $\delta 11.56-12.14 \mathrm{ppm}$. The hydrogen atom of the N-H group was observed downfield because of the presence of resonance and hydrogen bonds. The ${ }^{13} \mathrm{C}-\mathrm{NMR}$ signals of the carbonyl group, appearing at $\delta 169.75-170.61 \mathrm{ppm}$ were due to the existence of the intramolecular hydrogen bond related to the carbonyl oxygen atom. The carbon atom of the thiocarbonyl group at $\delta 179.06-182.27$ ppm showed the highest values.

The molecular structure of $\mathbf{5 d}$ was analyzed by single crystal X-ray diffraction method, and crystallographic data are: $\mathrm{C}_{23} \mathrm{H}_{19} \mathrm{~F}_{3} \mathrm{~N}_{2} \mathrm{O}_{2} \mathrm{~S}\left(\mathrm{Mr}=444.47 \mathrm{~g} \mathrm{~mol}^{-1}\right)$, triclinic, $a=7.1369(2) \AA, b=11.8876(3)$ $\AA, c=13.4640(9) \AA, \alpha=102.869(7)^{\circ}, \beta=91.557(6)^{\circ}, \gamma=104.241(7)^{\circ}, V=1075.31(10) \AA^{3}, \mathrm{~T}=293 \mathrm{~K}$, space group P-1 (\#2), Z = 2 (Table S1 from Supplementary Materials). The molecular structure (Figure S1 from Supplementary Materials) shows that 2-(4-ethylphenoxymethyl)benzoyl fragment is bonded to the 2,4,6-trifluorophenyl thiourea moiety. The $\mathrm{C}=\mathrm{O}$ and $\mathrm{C}=\mathrm{S}$ bonds are oriented in a trans configuration in a plane stabilized by an intramolecular hydrogen bond N2-H‥O2 (Figure 2). This plane forms a dihedral angle of $52.58^{\circ}$ with the central phenyl ring. This characteristic appears in similar structures involving the benzoyl fragment connected to a thiourea fragment, as was seen by searching the Cambridge Crystallographic Data Centre (CCDC) (e.g., ethyl 4-[3-(2-methylbenzoyl)thioureido]benzoate (FUGZOX code in CCDC) [46], or N-(2-methylbenzoyl)-N'-(4-nitrophenyl)thiourea (GOJNAV code in CCDC) [47]. The 4-ethylphenoxymethyl fragment forms with central phenyl ring a $30.85^{\circ}$ dihedral angle. The 2,4,6-trifluorophenyl ring forms with previous discussed plan another dihedral angle of $66.75^{\circ}$. Bond distances and angles are listed in the Tables S2 and S3. The unit cell contains two asymmetric units. The crystal packing for $\mathbf{5 d}$ (see Figures S1-S3) is based on hydrogen bonds' supramolecular interactions, implying the 2,4,6-trifluorophenyl fragment belongs to neighboring molecules, being at the same time hydrogen acceptor and donor. The C-H $\cdots \pi$ supramolecular interactions involve the ethyl and phenyl ring from the 4-ethylphenoxymethyl fragments from different molecules (Figure 3). 


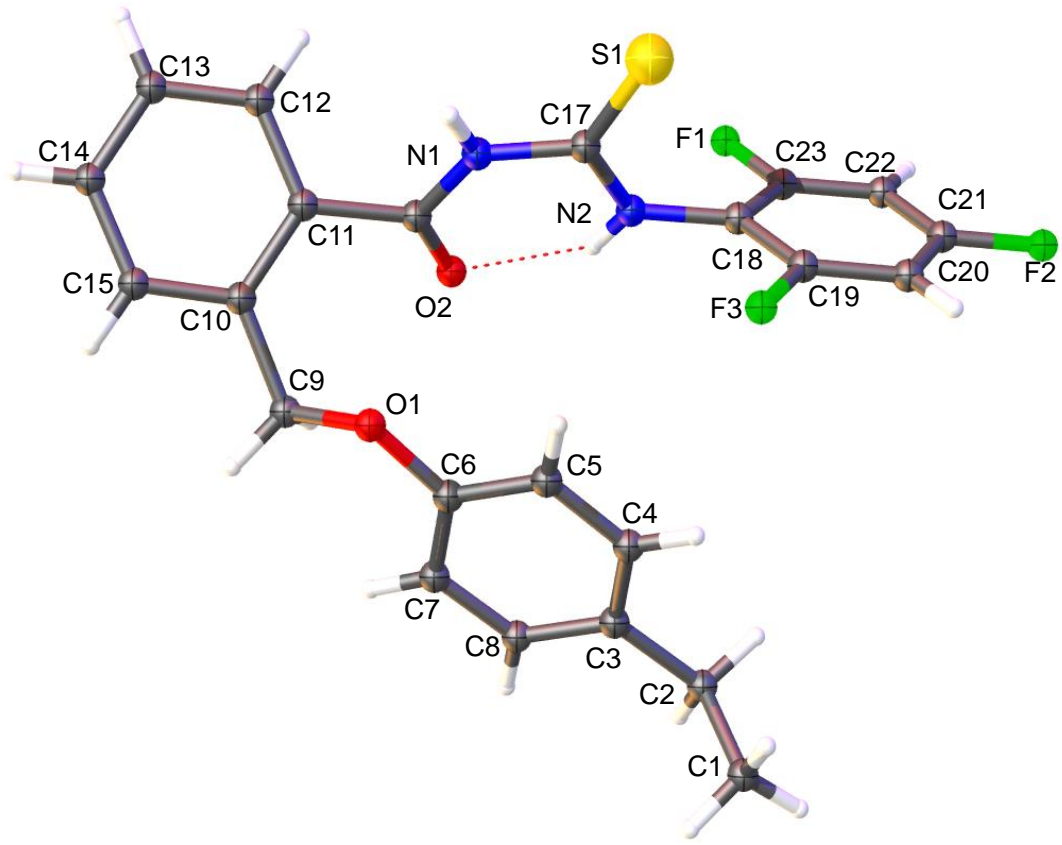

Figure 2. View of the asymmetric unit for $5 \mathbf{d}$ with the atom numbering scheme $(50 \%$ probability ellipsoid).

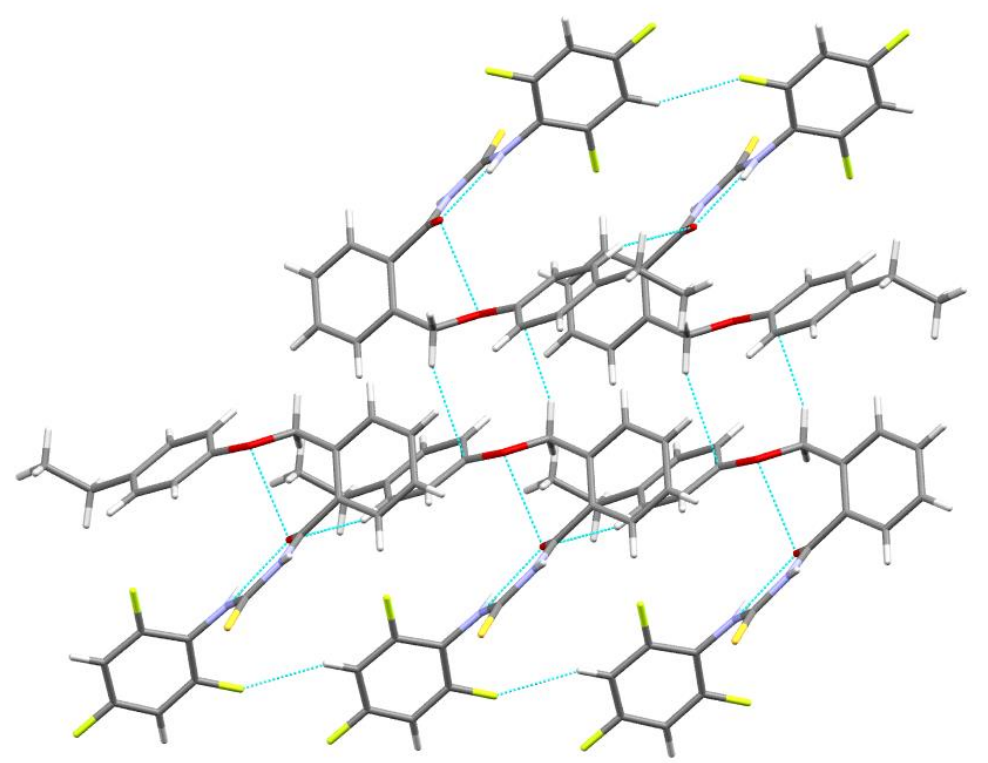

Figure 3. Details of supramolecular interactions in the crystal packing of $\mathbf{5 d}$.

\subsection{Computational Studies}

For the structure-activity relationship (SAR) studies, the following electronic properties were determined: Highest occupied molecular orbital (HOMO) and lowest unoccupied molecular orbital (LUMO) energy values, HOMO and LUMO orbital coefficients distribution, molecular dipole moment (for $\mathbf{5 d}$ compound 5.15 debye), polar surface area (for $\mathbf{5 d}$ compound PSA $=34.930 \AA^{2}$ ) (a descriptor that has been shown to correlate well with passive molecular transport through membranes and, therefore, allows thar predictions for the membrane transport properties), the ovality (for $\mathbf{5 d}$ compound 1.62 ), polarizability (for $\mathbf{5 d}$ compound $74.4210^{-30} \mathrm{~m}^{3}$ ), and the octanol water partition coefficient (for $\mathbf{5 d}$ compound $\log \mathrm{P}=6.29)$ [48]. 
Properties relating to 3D structure of $\mathbf{5 d}$ compound, bond lengths and angles, are presented in correlation with the experimental data (Tables S4 and S5). NMR spectra of $\mathbf{5 d}$ compound have been calculated with Spartan 14 software. The experimental and calculated spectra proved to be correlated (Table S6).

\subsubsection{Frontier Molecular Orbitals Analysis}

Frontier molecular orbitals (FMOs) (the most important being HOMO and LUMO) analysis are predicting for the chemical stability and interactions between atoms and dictating the optical properties and biological activities of a certain molecule. HOMO indicates one molecule's capacity to donate, while LUMO indicates one molecule's capacity to accept an electron $[49,50]$. The HOMO and LUMO, calculated at the B3LYP/6-31G* level can be seen in Figure 4 for compound 5d. The "blue and red" regions of the graphic correspond to the orbital's positive and negative values. The frontier orbital gap $(\Delta \mathrm{E})$ characterizes the chemical reactivity. The high value of the HOMO-LUMO gap $(\Delta \mathrm{E})$ calculated for the $\mathbf{5 d}$ compound refers to a chemically stable molecule [51].

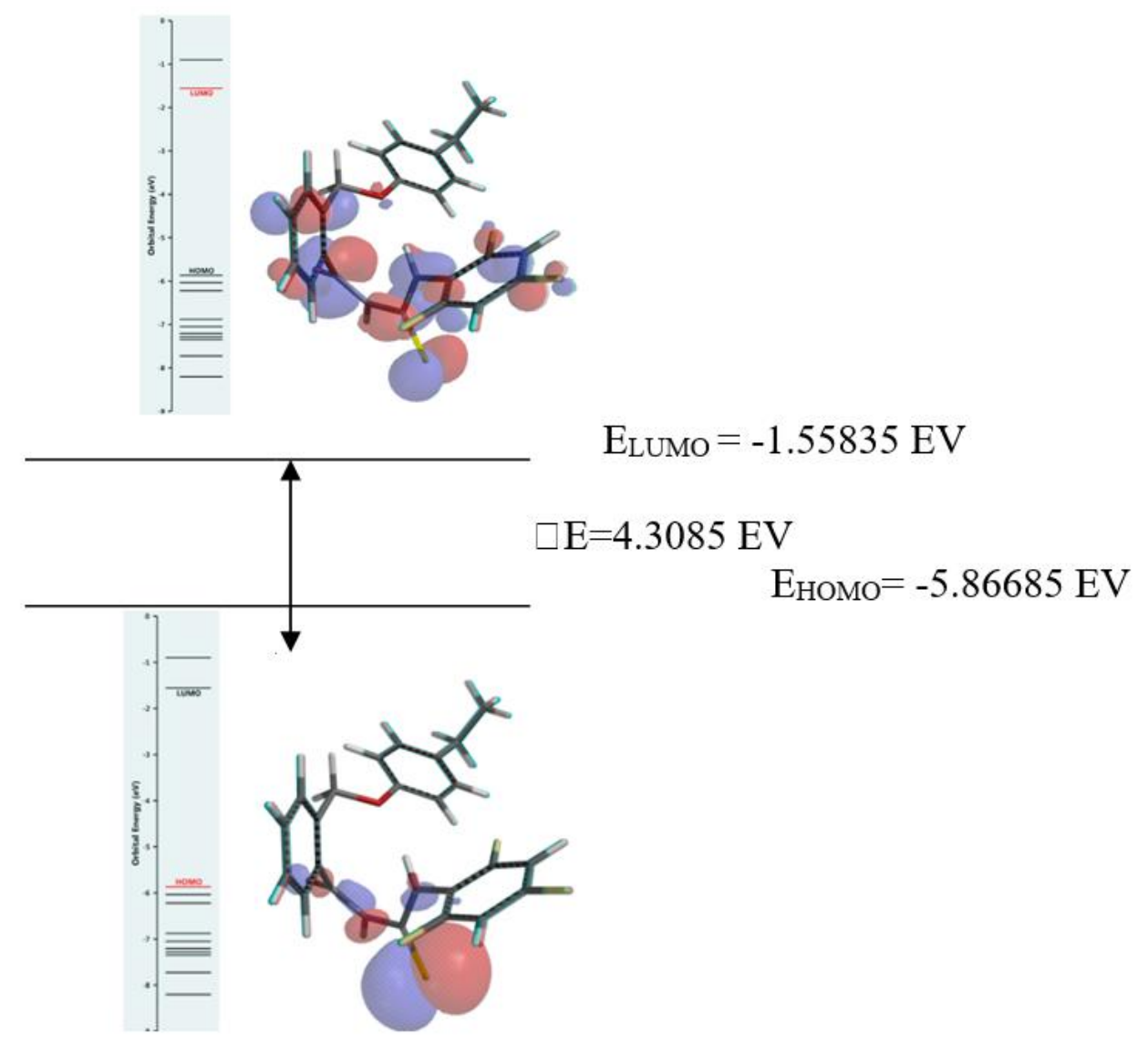

Figure 4. Highest occupied molecular orbital (HOMO) and lowest unoccupied molecular orbital (LUMO) surfaces of $\mathbf{5} \mathbf{d}$ compound.

\subsubsection{Molecular Electrostatic Potential (MEP)}

MEP has been evaluated using the B3LYP method with the basic set $6-31 G^{*}$ to investigate the chemical reactivity of a molecule, indicating the reactive sites of nucleophilic or electrophilic attack in hydrogen-bonding interactions involved in the biological recognition process [52,53]. The putative electrostatic map of the compound $\mathbf{5 d}$ shows hydrophilic regions in red (negative potential) and blue (positive potential) and hydrophobic regions in green (Figure 5a). The local ionization map is the result of the overlay of the energy of electron removal (ionization) on the electron density and can also 
indicate the electrophilic addition (Figure 5b). The LUMO map, representing a superposition of the absolute value of LUMO on the electron density indicates the nucleophilic addition (Figure 5c).
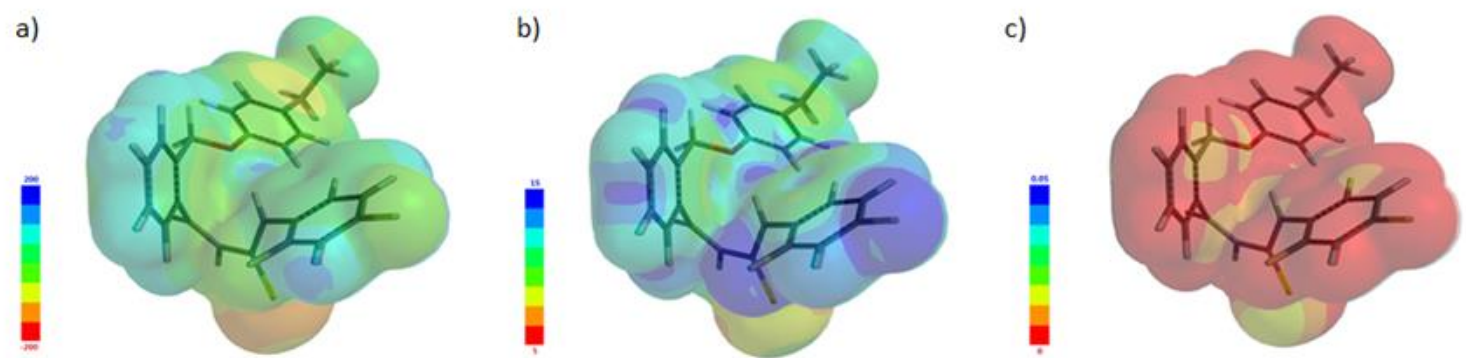

Figure 5. (a) The optimized geometry and electrostatic potential pattern of the surface of compound 5d (red, negative, high electron density; blue, positive area, low electron density). (b) The optimized geometry and local ionization potential map of compound $\mathbf{5 d}$. (c) The optimized geometry and LUMO map of compound $\mathbf{5 d}$.

\subsubsection{Docking Studies}

Molecular docking allowed us to establish an accurate prediction of the optimized conformation of new compounds (as ligands) and their target receptor protein in order to achieve a stable complex.

The score and hydrogen bonds formed with the amino acids from group interaction atoms are used to predict the binding modes, the binding affinities and the orientation of the docked substances (Figure 6a-i and Figure S4a-z) in the active site of the protein receptor (Table S7). The docking score used in the Drug Discovery Workbench is the PLANTSPLP score [52].

The ligand orientation and position suggested by the molecular docking studies and the binding modes of ligands have been validated by redocking (Figure 6c,e,h, and Figure S4). According to the docking score evaluation, the best docking score was obtained for 5e: -63.91 (RMSD 0.10). The compound 5e shows three hydrogen bonds with ASN 45 (2.870 ̊), ILE 78 (3.244 ̊) and GLY 77 $(2.924 \AA)$ and its orientation is different from the co-crystallized one. The same orientation of the co-crystallized is shown by the the compounds $\mathbf{5 b}, \mathbf{5 c}, \mathbf{5 d}$, and $\mathbf{5 f}$ (Figure $7 \mathrm{a}$ ). The compounds $\mathbf{5 a}$ and $5 \mathrm{~g}$ show also the same orientation as the $5 \mathbf{e}$ compound (Figure $7 \mathrm{~b}$ ).

The results for $\mathbf{5 d}$ compound revealed a docking score -56.80 (RMSD 0.20) and two hydrogen bonds with GLY 101 (3.144 ̊̊ and $3.381 \AA$ ) (Figure 6d).

The docking studies revealed that compounds 5e (docking score -63.91, RMSD 0.22), 5a (docking score -61.58, RMSD 0.05), 5g (docking score -59.92, RMSD 0.24), 5b (docking score-59.66, RMSD 0.46) and 5d (docking score -56.81, RMSD 0.20 ) presented a good docking score (Table S7). After correlating the in silico prediction with the experimental data, it was observed that all these four compounds displayed the same activity against E. coli (MIC: $128 \mu \mathrm{g} / \mathrm{mL}$ ). Also, it has been observed that the compounds 5c (docking score -57.73, RMSD 0.08) and 5f (docking score -56.18, RMSD 0.22) displayed a lower activity against E. coli (MIC: $>256 \mu \mathrm{g} / \mathrm{mL})$.

The number of hydrogen bond donors, the number of hydrogen bond acceptors, and $\log \mathrm{P}$ were calculated and are presented in Table 1. The calculated parameters can predict if a molecule possesses properties that might turn it into an active drug, according to the Lipinski's rule of five [53]: The number of hydrogen donors $<5$, the number of hydrogen acceptors $<10$, molecular weight $<500 \mathrm{Da}$, and the octanol-water partition coefficient $(\log P)<5$. The $\log P$ calculation was performed using the XLOGP3-AA method [54]. 

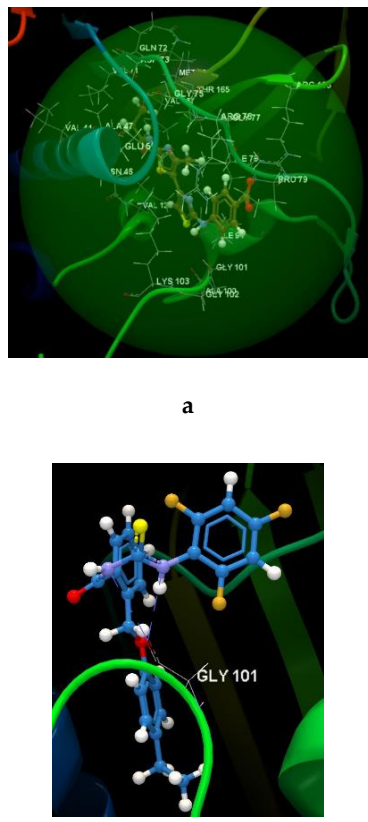

d

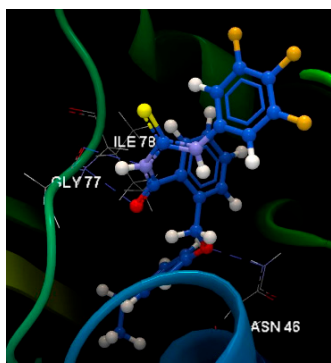

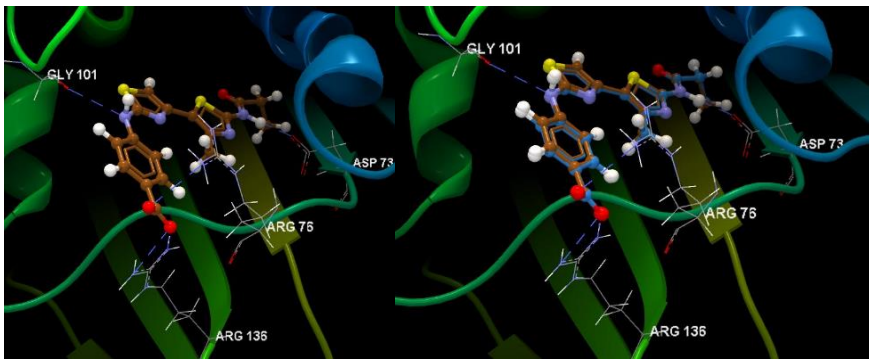
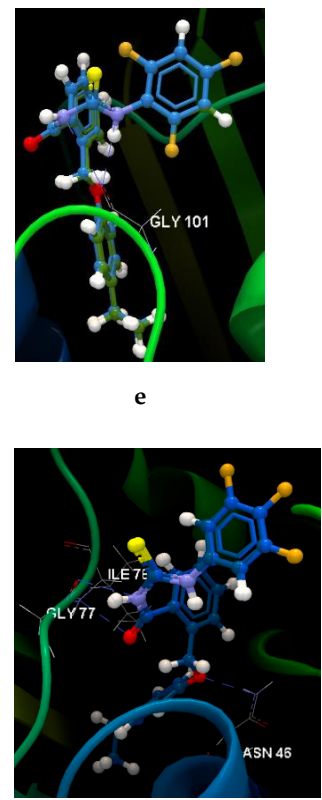

h

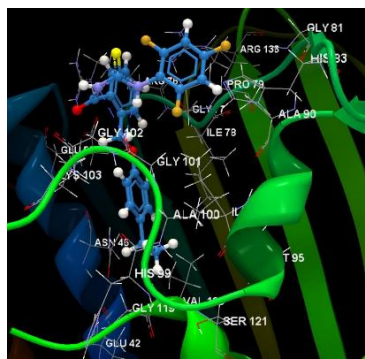

$\mathbf{f}$

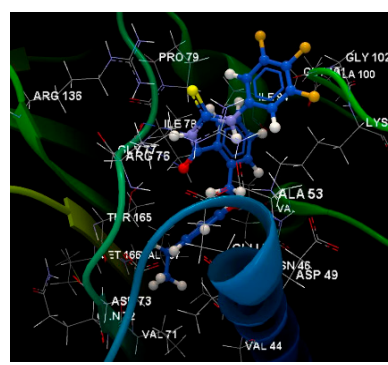

i

Figure 6. Molecular docking studies with the 4DUH receptor. (a) Binding site and docking pose of the co-crystallized ligand interacting with residues. (b) Hydrogen bonds between the residues of the ARG 136, ARG 76, GLT 101 and ASP 73 and the co-crystallized. (c) Docking validation of co-crystallized ligand. (d) Hydrogen bonds between the residues of the GLY 101 and the 5d ligand. (e) Docking validation of $\mathbf{5 d}$. (f) Docking pose of the $\mathbf{5 d}$ interacting with residues in the binding site. (g) Hydrogen bonds between the residues of the ASN 46, ILE 78, GLY 77 and the 5e ligand. (h) Docking validation of 5e. (i) Docking pose of the $5 \mathbf{e}$ interacting with residues in the binding site.

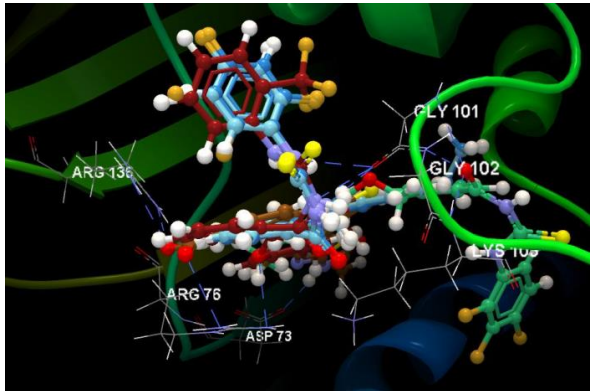

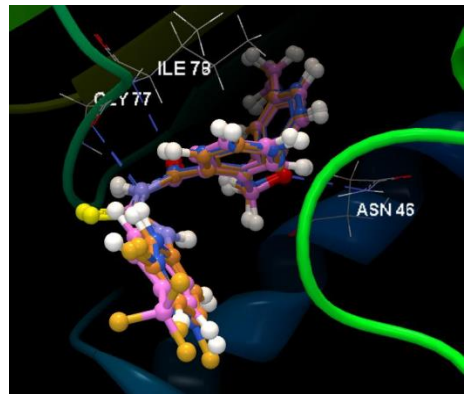

Figure 7. Docking pose of the new benzoylthiourea derivatives in the binding site of 4DUH. (a) The derivatives with the similar binding mode of the co-crystallized (brown): $5 \mathbf{b}$, light green; $\mathbf{5 c}$, ice blue; $\mathbf{5 d}$, sky blue; $5 \mathbf{f}$, brick. (b) The derivatives with a different binding mode from the co-crystallized (5a, nut brown; $5 \mathbf{e}$, blue; $5 \mathrm{~g}$, soft pink). 
Table 1. Ligands' molecular properties values.

\begin{tabular}{|c|c|c|c|c|c|c|c|}
\hline Compound & Atoms & $\begin{array}{c}\text { Weight } \\
\text { [Daltons] }\end{array}$ & $\begin{array}{c}\text { Flexible } \\
\text { Bonds }\end{array}$ & $\begin{array}{c}\text { Lipinski } \\
\text { Violations }\end{array}$ & $\begin{array}{c}\text { Hydrogen } \\
\text { Donors }\end{array}$ & $\begin{array}{l}\text { Hydrogen } \\
\text { Acceptors }\end{array}$ & $\log P * *$ \\
\hline Co-crystallized * & 41 & 387.46 & 6 & 1 & 2 & 7 & 5.10 \\
\hline $5 a$ & 50 & 408.49 & 6 & 1 & 2 & 4 & 5.52 \\
\hline $5 b$ & 50 & 444.47 & 6 & 1 & 2 & 4 & 5.72 \\
\hline $5 c$ & 50 & 444.47 & 6 & 1 & 2 & 4 & 5.72 \\
\hline $5 d$ & 50 & 444.47 & 6 & 1 & 2 & 4 & 5.72 \\
\hline $5 e$ & 50 & 447.47 & 6 & 1 & 2 & 4 & 5.72 \\
\hline $5 f$ & 53 & 458.50 & 7 & 1 & 2 & 4 & 6.31 \\
\hline $5 g$ & 53 & 458.50 & 7 & 1 & 2 & 4 & 6.31 \\
\hline
\end{tabular}

* co-crystallized: 4-\{[4'-methyl-2'-(propanoylamino)-4,5'-bi-1,3-thiazol-2-yl]amino\}benzoic acid. ** The log P calculation was performed using the XLOGP3-AA method [54].

\subsection{Antimicrobial Activity Assay}

The synthesized compounds were tested by a quantitative method, allowing us to establish the MIC (minimum inhibitory concentration) value (Table 2). The compounds $\mathbf{5} \mathbf{c}$ and $\mathbf{5} \mathbf{f}$ proved to have a low inhibitory effect against the tested strains. The compounds encoded $\mathbf{5 a}$ and $\mathbf{5 b}$ proved to be active against $E$. coli and P. aeruginosa strains, exhibiting the same MIC value. The compound $\mathbf{5 d}$ exhibited both antibacterial and antifungal activity, being active on E. coli and C. albicans strains. The compound $5 \mathbf{a}$ exhibited the largest spectrum of antibacterial activity, being active both against Gram-positive and -negative strains. Interestingly, the largest spectrum of activity of the compound $\mathbf{5 a}$ was correlated with the presence of one fluorine atom as substituent on the phenyl ring.

Table 2. The inhibitory activity of the new F-compounds 5a-g on the planktonic growth of the tested microbial strains. The minimum inhibitory concentration (MIC) expressed in $\mu \mathrm{g} / \mathrm{mL}$ of the new fluoro compounds $(\mathbf{5 a}-\mathbf{g})$ are presented as the average of three different experiments. The most active compounds are highlighted.

\begin{tabular}{lccccccc}
\hline & $\mathbf{5 a}$ & $\mathbf{5 b}$ & $\mathbf{5 c}$ & $\mathbf{5 d}$ & $\mathbf{5 e}$ & $\mathbf{5 f}$ & $\mathbf{5 g}$ \\
\hline E. coli ATCC 25992 & 128 & $\mathbf{1 2 8}$ & $>256$ & 128 & 128 & $>256$ & 128 \\
$\begin{array}{l}\text { P. aeruginosa ATCC } \\
27853\end{array}$ & 128 & 128 & $>256$ & $>256$ & $>256$ & $>256$ & $>256$ \\
S. aureus ATCC 25923 & $>128$ & $>128$ & $>128$ & $>128$ & $>128$ & $>128$ & $>128$ \\
E. faecalis ATCC 29212 & 128 & $>256$ & $>256$ & $>256$ & $>256$ & $>256$ & $>256$ \\
B. subtilis ATCC 6633 & $>128$ & $>128$ & $>128$ & $>128$ & $>128$ & $>128$ & $>128$ \\
C. albicans ATCC 10231 & $>128$ & $>128$ & $>128$ & 64 & $>128$ & $>128$ & $>128$ \\
\hline
\end{tabular}

Compared to the Gram-positive strains, the Gram-negative bacterial strains proved to be more susceptible to the tested compounds, with five of the seven tested compounds being active against the E. coli strain. S. aureus and B. subtilis proved to be resistant to all tested compounds, while E. faecalis and C. albicans were susceptible to only one compound, respectively, $\mathbf{5 a}$ and $\mathbf{5 d}$ (Table 2).

The presence of multiple fluorine atoms (e.g., three atoms in the compounds $\mathbf{5 b}, \mathbf{5 c}, \mathbf{5 d}$, and $\mathbf{5 e}$ ) located at different positions in the compounds did not correlate with the intensity of the antibacterial effect, with three of them exhibiting the same anti-E. coli activity similar to $5 \mathbf{a}$, with the other one displaying a lower activity against the same strain. All of them were inactive on E. faecalis and all but $\mathbf{5 b}$ against $P$. aeruginosa when compared with $5 \mathbf{a}$. The compounds substituted with the trifluoromethyl group $(5 \mathbf{e}$ and $5 \mathbf{g}$ ) were active on E. coli. Further, the presence of three fluorine atoms in the positions 2 , 4 , and 6 conferred antifungal properties for the compound $\mathbf{5 d}$.

The antibiofilm activity spectrum was different from that obtained on planktonic strains, with all tested compounds being able to inhibit the formation of biofilms formed by at least two of the tested strains. The E. coli, S. aureus, and B. subtilis biofilms were the most recalcitrant to the tested compounds, with a maximum of three compounds exhibiting antibiofilm activity (Table 3). The $E$. faecalis and C. albicans biofilms were susceptible to the tested compounds, excepting $5 \mathbf{c}$ and $\mathbf{5 g}$. The 
most active compounds on the development of microbial biofilms proved to be those substituted by the trifluoromethyl group, the most favorable substitution being in para position (Table 3).

Table 3. The inhibitory activity of the new F-compounds 5a-g on the microbial biofilm development on the inert substratum (the most active compounds are highlighted).

\begin{tabular}{lccccccc}
\hline & $\mathbf{5 a}$ & $\mathbf{5 b}$ & $\mathbf{5 c}$ & $\mathbf{5 d}$ & $\mathbf{5 e}$ & $\mathbf{5 f}$ & $\mathbf{5 g}$ \\
\hline E. coli ATCC 25992 & $\mathrm{A}$ & $\mathrm{A}$ & $\mathrm{A}$ & $\mathrm{A}$ & $\mathrm{I}$ & $\mathrm{A}$ & $\mathrm{I}$ \\
$\begin{array}{l}\text { P. aeruginosa ATCC } \\
27853\end{array}$ & $\mathrm{~A}$ & $\mathrm{I}$ & $\mathrm{I}$ & $\mathrm{I}$ & $\mathrm{I}$ & $\mathrm{I}$ & $\mathrm{I}$ \\
S. aureus ATCC 25923 & $\mathrm{I}$ & $\mathrm{A}$ & $\mathrm{I}$ & $\mathrm{A}$ & $\mathrm{A}$ & $\mathrm{A}$ & $\mathrm{I}$ \\
E. faecalis ATCC 29212 & $\mathrm{I}$ & $\mathrm{I}$ & $\mathrm{I}$ & $\mathrm{I}$ & $\mathrm{I}$ & $\mathrm{I}$ & $\mathrm{I}$ \\
B. subtilis ATCC 6633 & $\mathrm{I}$ & $\mathrm{A}$ & $\mathrm{I}$ & $\mathrm{A}$ & $\mathrm{A}$ & $\mathrm{I}$ & $\mathrm{A}$ \\
C. albicans ATCC 10231 & $\mathrm{I}$ & $\mathrm{A}$ & $\mathrm{A}$ & $\mathrm{I}$ & $\mathrm{I}$ & $\mathrm{I}$ & $\mathrm{I}$ \\
\hline
\end{tabular}

I: Inhibitory activity on the biofilm development. A: Absence of any inhibitory activity on the biofilm development.

\section{Discussion}

The emergence and spread of antimicrobial resistance have become some of the major worldwide health problems today, raising the acute need for developing novel antimicrobial agents. Considering the valuable pharmacological properties of thiourea derivatives, our aim was to design, synthesize and evaluate new compounds with fluorinated and trifluoromethylated aryl thiourea scaffolds. Fluorine substitution can improve the efficacy of drugs by influencing the absorption, tissue distribution, the rate and the route of biotransformation, the pharmacodynamic and the toxicological properties. Our interest was to optimize the substitution atoms or the functional groups present on the phenyl bound to nitrogen atom of thiourea in order to increase the antimicrobial activity of the obtained derivatives.

In this direction, we synthesized new 2-((4-ethylphenoxy)methyl)- $N$-(fluoro/trifluoromethylphenylcarbamothioyl)benzamides, and evaluated their antimicrobial activity.

The best antibacterial activity (against E. coli, P. aeruginosa, and E. faecalis) was recorded for the compounds bearing one fluorine atom, while the antifungal effect was favored by the isomeric substitution with three fluorine atoms. The $\mathbf{5 d}$ exhibited the lowest recorded MIC value against the C. albicans fungal strain. This effect could be explained by the enhancement of lipid solubility and permeability of the fungal cell wall, with a particular structure owing to the eukaryotic nature of this microorganism, for the antimicrobial compound.

The spectrum of the antibiofilm activity was different from that recorded on planktonic cells, with all tested compounds inhibiting the ability of some microbial strains to form biofilms. The intensity of this activity was correlated with the presence of the trifluoromethyl substituent, most favorably in para position and the compound $5 \mathrm{~g}$ being the most active.

Despite the great susceptibility of planktonic E. coli cells to the majority of the tested compounds, the adherent $E$. coli cells were more resistant, remaining susceptible to only two compounds $(\mathbf{5 e}, 5 \mathbf{g})$. This could account for the increased tolerance of microbial biofilms to the usual doses of antibiotics.

It is worth noting that $P$. aeruginosa biofilms were highly susceptible to the all tested compounds, except 5a.

Some electronic and molecular properties were discussed in order to assess the flexibility and the binding ability of the studied conformer to bind to the receptor protein. The docking studies using E. coli DNA gyrase B revealed that all compounds showed a good docking score, indicating the inhibition of DNA replication as a potential mechanism of their antimicrobial activity that is worth to be studied further.

\section{Materials and Methods}

\subsection{Chemistry}

Highest quality phthalide, $p$-ethylphenol, ammonium thiocyanate, primary aromatic amines, and thionyl chloride used for the synthesis were purchased from Sigma-Aldrich Chemical Co. Analytical 
grade solvents (1,2-dichloroethane, xylene, isopropanol, acetone) supplied by Sigma- Aldrich were used and were dried when necessary. Potassium hydroxide and hydrochloric acid were obtained from Merck, and potassium carbonate from Fluka Chemical.

Acetone was dried over $\mathrm{K}_{2} \mathrm{CO}_{3}$ and then distilled. Ammonium thiocyanate was heated at $100{ }^{\circ} \mathrm{C}$ before use. The liquid amines were dried with potassium hydroxide and then distilled.

The reaction progress and the purity were investigated by thin layer chromatography on silica gel 60 F254 (0.5 mm thick) plates (Merck, Germany) and unidimensional migration using ethyl acetate/cyclohexane (4:6 v/v) as eluent with visualization by ultraviolet light $(\lambda=254 \mathrm{~nm})$ and exposed to iodine vapors.

Melting points were measured by heating a small amount of sample, by the capillary tube method, using an Electrothermal 9100 apparatus (Bibby Scientific Ltd., Stone, UK), without thermometer correction. The tube was observed with a magnifying glass, with a temperature range of $0.5-1.0^{\circ} \mathrm{C}$ indicating a relatively high level of purity.

C, H, N, and S analyses were performed on a Perkin Elmer 2400 Series II CHNS/O Elemental Analyzer (Waltham, MA, USA), using the classical Pregl-Dumas method, and considering an accepted deviation of elemental analysis results from the calculated one of $0.4 \%$.

The FTIR spectra were recorded with a Bruker Vertex-70 spectrophotometer (Bruker Corporation, Billerica, MA, USA) with an optical system with diamond. The IR bands were given as w (weak), $\mathrm{m}$ (medium), s (intense), and vs (very intense) and were obtained using attenuated total reflection Fourier-transformed infrared (ATR-FTIR) spectra at room temperature.

NMR spectra were recorded on a Varian Unity Inova 400 instrument operating at $400 \mathrm{MHz}$ for ${ }^{1} \mathrm{H}, 100 \mathrm{MHz}$ for ${ }^{13} \mathrm{C}$, and $376.3 \mathrm{MHz}$ for ${ }^{19} \mathrm{~F}-\mathrm{NMR}$ (Varian Medical Systems, Palo Alto, CA, USA). As solvent, we used perdeuterated dimethyl sulfoxide with a min. $98 \%$ isotopic purity. The spectra were recorded at a temperature of $20 \pm 1{ }^{\circ} \mathrm{C}$. In order to perform the right attribution of spectral signals, we used different techniques to simplify the spectra, like the homonuclear decoupling and the specific deuteration.

The 2-(4-ethyl-phenoxymethyl)benzoic acid (2) and 2-(4-ethyl-phenoxymethyl)benzoyl chloride (3) derivatives were obtained with good yields, following the method described in [55].

\subsubsection{General Synthesis Procedure of the New Benzoylthiourea Derivatives}

To a solution of ammonium thiocyanate $(0.01 \mathrm{~mol})$ in acetone $(5 \mathrm{~mL})$ we added a solution of 2-(4-ethylphenoxymethyl)benzoyl chloride (3) $(0.01 \mathrm{~mol})$ in acetone $(15 \mathrm{~mL})$ to obtain in situ arylisothiocyanate (4). The reaction mixture was refluxed for $1 \mathrm{~h}$, and then cooled at room temperature. A primary amine solution $(0.01 \mathrm{~mol})$ in acetone $(2 \mathrm{~mL})$ was added to the mixture and refluxed for 1 h. After cooling, the compound was precipitated and poured into $500 \mathrm{~mL}$ cold water, the solid was filtered, dried, and then recrystallized from isopropanol with active carbon.

2-((4-Ethylphenoxy)methyl)-N-(3-fluorophenylcarbamothioyl)benzamide (5a), $3.18 \mathrm{~g}$ white crystals (yield $78 \%)$, mp $109-110{ }^{\circ} \mathrm{C}$.

${ }^{1} \mathrm{H}-\mathrm{NMR}$ (DMSO-d6): 12.52 (br s, $\left.1 \mathrm{H}, \mathrm{NH}\right), 11.92$ (br s, $\left.1 \mathrm{H}, \mathrm{NH}\right), 7.70\left(\mathrm{dt},{ }^{4} J_{(\mathrm{H} 18-\mathrm{H} 20,22)}=2.2 \mathrm{~Hz}\right.$, $\left.{ }^{3} J_{(\mathrm{F}-\mathrm{H} 18)}=10.9 \mathrm{~Hz}, 1 \mathrm{H}, \mathrm{H}-18\right), 7.62(\mathrm{dd}, J=1.2 \mathrm{~Hz}, J=7.6 \mathrm{~Hz}, 1 \mathrm{H}, \mathrm{H}-7), 7.60(\mathrm{~m}, 1 \mathrm{H}, \mathrm{H}-4), 7.58(\mathrm{td}$, $J=1.4 \mathrm{~Hz}, J=7.4 \mathrm{~Hz}, 1 \mathrm{H}, \mathrm{H}-5), 7.47(\mathrm{td}, J=1.4 \mathrm{~Hz}, J=7.5 \mathrm{~Hz}, 1 \mathrm{H}, \mathrm{H}-6), 7.43\left(\mathrm{td},{ }^{4} J_{(\mathrm{H} 21-\mathrm{F})}=6.6 \mathrm{~Hz}\right.$, $\left.{ }^{3} J_{(\mathrm{H} 21-\mathrm{H} 20,22)}=8.2 \mathrm{~Hz}, 1 \mathrm{H}, \mathrm{H}-21\right), 7.34\left(\mathrm{ddd},{ }^{4} J_{(\mathrm{H} 22-\mathrm{H} 20)}=1.0 \mathrm{~Hz},{ }^{4} J_{(\mathrm{H} 18-\mathrm{H} 22)}=2.2 \mathrm{~Hz},{ }^{3} J_{(\mathrm{H} 22-\mathrm{H} 21)}=8.2\right.$ $\mathrm{Hz}, 1 \mathrm{H}, \mathrm{H}-22), 7.09\left(\mathrm{tdd},{ }^{4} J_{(\mathrm{H} 22-\mathrm{H} 20)}=1.0 \mathrm{~Hz},{ }^{4} J_{(\mathrm{H} 18-\mathrm{H} 20)}=2.2 \mathrm{~Hz},{ }^{3} J_{(\mathrm{H} 20-\mathrm{H} 21)}=8.2 \mathrm{~Hz},{ }^{3} J_{(\mathrm{H} 20-\mathrm{F})}=8.2\right.$ Hz, 1H, H-20), 7.08 (d, J = 8.6 Hz, 2H, H-11, H-13), 6.89 (d, J = 8.6 Hz, 2H, H-10, H-14), 5.28 (s, 2H, H-8), $2.50(\mathrm{q}, J=7.5 \mathrm{~Hz}, 2 \mathrm{H}, \mathrm{H}-15), 1.12\left(\mathrm{t}, J=7.5 \mathrm{~Hz}, 3 \mathrm{H}, \mathrm{H}-15^{\prime}\right)$ (Figure S5a,b).

${ }^{13}$ C-NMR (DMSO-d6): 179.06 (C-16), $170.13(\mathrm{C}-1), 161.62\left(\mathrm{~d}, J_{(\mathrm{F}-\mathrm{C} 19)}=241.3 \mathrm{~Hz}, \mathrm{C}-19\right), 156.28$ (C-9), $139.47\left(\mathrm{~d},{ }^{3} J_{(\mathrm{F}-\mathrm{C} 17)}=10.6 \mathrm{~Hz}, \mathrm{C}-17\right), 136.18(\mathrm{Cq}), 135.86(\mathrm{Cq}), 133.21(\mathrm{Cq}), 131.01(\mathrm{C}-5), 130.16\left(\mathrm{~d}, J_{(\mathrm{F}-\mathrm{C} 21)}\right.$ $=9.6 \mathrm{~Hz}, \mathrm{C}-21), 128.56(\mathrm{C}-11, \mathrm{C}-13), 128.45(\mathrm{C}-4), 128.33(\mathrm{C}-7), 127.69(\mathrm{C}-6), 120.11\left(\mathrm{~d},{ }^{4} J_{(\mathrm{F}-\mathrm{C} 22)}=2.9 \mathrm{~Hz}\right.$, 
C-22), $114.53(\mathrm{C}-10, \mathrm{C}-14), 112.84\left(\mathrm{~d}, J_{(\mathrm{F}-\mathrm{C} 20)}=20.9 \mathrm{~Hz}, \mathrm{C}-20\right), 111.03\left(\mathrm{~d}, J_{(\mathrm{F}-\mathrm{C} 18)}=25.6 \mathrm{~Hz}, \mathrm{C}-18\right), 67.49$ (C-8), 27.23 (C-15), 15.70 (C-15') (Figure S5c,d).

${ }^{19} \mathrm{~F}-\mathrm{NMR}$ (DMSO-d6): $-112.59\left(\mathrm{dd}, \mathrm{F},{ }^{3} J_{(\mathrm{H} 20-\mathrm{F})}=8.2 \mathrm{~Hz},{ }^{3} J_{(\mathrm{F}-\mathrm{H} 18)}=10.9 \mathrm{~Hz}\right)$.

FTIR (solid in ATR, $v \mathrm{~cm}^{-1}$ ): 3163s, 3028m, 2966m, 2934m, 2881m, 1688m, 1602m, 1514vs, $1452 \mathrm{~s}$, $1378 \mathrm{~m}, 1300 \mathrm{~m}, 1273 \mathrm{~m}, 1245 \mathrm{~s}, 1172 \mathrm{~s}, 1139 \mathrm{~s}, 1076 \mathrm{~m}, 1013 \mathrm{~m}, 982 \mathrm{w}, 897 \mathrm{w}, 860 \mathrm{w}, 827 \mathrm{~m}, 777 \mathrm{w}, 723 \mathrm{~m}$, $643 \mathrm{w}, 608 \mathrm{w}$.

Anal. Calcd for $\mathrm{C}_{23} \mathrm{H}_{21} \mathrm{FN}_{2} \mathrm{O}_{2} \mathrm{~S}$ (408.49): $\mathrm{C}, 67.63 ; \mathrm{H}, 5.18 ; \mathrm{N}, 7.83 ; \mathrm{S}, 7.85 \%$. Found: $\mathrm{C}, 67.31 ; \mathrm{H}$, $4.97 ; \mathrm{N}, 7.74 ; \mathrm{S} 8.01 \%$.

2-((4-Ethylphenoxy)methyl)-N-(2,3,4-trifluorophenylcarbamothioyl)benzamide (5b) $3.37 \mathrm{~g}$ white crystals (yield $76 \%$ ), mp 107-108 ${ }^{\circ} \mathrm{C}$.

${ }^{1} \mathrm{H}-\mathrm{NMR}$ (DMSO-d6): 12.14 (br s, 1H, NH), 12.11 (br s, 1H, NH), $7.63(\mathrm{dd}, J=1.2 \mathrm{~Hz}, J=7.61 \mathrm{~Hz}$, 1H, H-7), 7.61- 7.51 (m, 3H, H-4, H-5, H-22), 7.47 (td, $J=1.4 \mathrm{~Hz}, J=7.5 \mathrm{~Hz}, 1 \mathrm{H}, \mathrm{H}-6), 7.35$ (td, ${ }^{4} J_{(\mathrm{H} 21-\mathrm{F} 19)}$ $\left.=2.2 \mathrm{~Hz},{ }^{3} J_{(\mathrm{H} 21-\mathrm{F} 20)}=9.4 \mathrm{~Hz},{ }^{3} J_{(\mathrm{H} 21-\mathrm{H} 22)}=9.4 \mathrm{~Hz}, 1 \mathrm{H}, \mathrm{H}-21\right), 7.08(\mathrm{~d}, J=8.6 \mathrm{~Hz}, 2 \mathrm{H}, \mathrm{H}-11, \mathrm{H}-13), 6.89$ $(\mathrm{d}, J=8.6 \mathrm{HZ}, 2 \mathrm{H}, \mathrm{H}-10, \mathrm{H}-14), 5.27(\mathrm{~s}, 2 \mathrm{H}, \mathrm{H}-8), 2.50(\mathrm{q}, J=7.5 \mathrm{~Hz}, 2 \mathrm{H}, \mathrm{H}-15), 1.13(\mathrm{t}, J=7.5 \mathrm{~Hz}, 3 \mathrm{H}$, H-15') (Figure S6a,b).

${ }^{13}$ C-NMR (DMSO-d6): 181.10 (C-16), $170.13(\mathrm{C}-1), 156.22(\mathrm{C}-9), 148.72\left(\mathrm{ddd},{ }^{3} J_{(\mathrm{C} 18-\mathrm{F} 20)}=2.6 \mathrm{~Hz}\right.$, $\left.{ }^{2} J_{(\mathrm{C} 18-\mathrm{F} 19)}=9.9 \mathrm{~Hz}, J_{(\mathrm{C}-\mathrm{F})}=245.7 \mathrm{~Hz}, \mathrm{C}-18\right), 145.47\left(\mathrm{ddd},{ }^{3} J_{(\mathrm{C} 20-\mathrm{F} 18)}=3.6 \mathrm{~Hz},{ }^{2} J_{(\mathrm{C} 20-\mathrm{F} 19)}=9.9 \mathrm{~Hz}\right.$, $\left.J_{(\mathrm{C} 20-\mathrm{F} 20)}=249.7 \mathrm{~Hz}, \mathrm{C}-20\right), 139.23\left(\mathrm{dt},{ }^{2} J_{(\mathrm{C} 19-\mathrm{F} 18,20)}=9.9 \mathrm{~Hz}, J_{(\mathrm{C} 19-\mathrm{F} 19)}=246.8 \mathrm{~Hz}, \mathrm{C}-19\right), 136.23(\mathrm{Cq})$, 135.87 (Cq), 133.08 (Cq), 131.07 (C-5), 128.56 (C-11, C-13), 128.42 (C-4, C-7), 127.72 (C-6), 124.27 (dd, $\left.{ }^{3} J_{(\mathrm{C} 17-\mathrm{F} 19)}=3.7 \mathrm{~Hz},{ }^{2} J_{(\mathrm{C} 17-\mathrm{F} 18)}=9.1 \mathrm{~Hz}, \mathrm{C}-17\right), 122.71\left(\mathrm{dd},{ }^{3} J_{(\mathrm{C} 22-\mathrm{F} 18)}=3.7 \mathrm{~Hz},{ }^{3} J_{(\mathrm{C} 22-\mathrm{F} 20)}=8.1 \mathrm{~Hz}, \mathrm{C}-22\right)$, $114.59(\mathrm{C}-10, \mathrm{C}-14), 111.62\left(\mathrm{dd},{ }^{3} J\left(\mathrm{C}^{21}-\mathrm{F}^{19}\right)=3.7 \mathrm{~Hz},{ }^{2} \mathrm{~J}\left(\mathrm{C}^{21}-\mathrm{F}^{20}\right)=17.6 \mathrm{~Hz}, \mathrm{C}-21\right), 67.51(\mathrm{C}-8), 27.25$ (C-15), 15.77 (C-15') (Figure S6c).

${ }^{19} \mathrm{~F}-\mathrm{NMR}$ (DMSO-d6): $-161.03\left(\mathrm{dq},{ }^{4} J_{(\mathrm{F} 20-\mathrm{F} 18)}=6.0 \mathrm{~Hz},{ }^{4} J_{(\mathrm{F} 20-\mathrm{H} 22)}=6.0 \mathrm{~Hz},{ }^{3} J_{(\mathrm{F} 20-\mathrm{F} 19)}=21.8 \mathrm{~Hz}\right.$, $\mathrm{F}-20),-140.50\left(\mathrm{dt},{ }^{3} J_{(\mathrm{F} 18-\mathrm{F} 20)}=6.0 \mathrm{~Hz},{ }^{3} J_{(\mathrm{F} 18-\mathrm{H} 22)}=6.0 \mathrm{~Hz},{ }^{3} J_{(\mathrm{F} 18-\mathrm{F} 19)}=21.8 \mathrm{~Hz}, \mathrm{~F}-18\right),-136.78(\mathrm{td}$, $\left.{ }^{4} J_{(\mathrm{H} 21-\mathrm{F} 19)}=9.4 \mathrm{~Hz},{ }^{3} J_{(\mathrm{F} 19-\mathrm{F} 18,20)}=21.8 \mathrm{~Hz}, \mathrm{~F}-19\right)$.

FTIR (solid in ATR, $v \mathrm{~cm}^{-1}$ ): 3155m, 3064m, 2970m, 2873w, 1691s, 1616w, 1506vs, 1381w, 1315m, $1256 \mathrm{~m}, 1215 \mathrm{~m}, 1174 \mathrm{~s}, 1070 \mathrm{~s}, 1045 \mathrm{~m}, 994 \mathrm{~m}, 907 \mathrm{w}, 875 \mathrm{w}, 826 \mathrm{w}, 725 \mathrm{~m}, 692 \mathrm{~m}, 658 \mathrm{w}, 600 \mathrm{w}$.

Anal. Calcd for $\mathrm{C}_{23} \mathrm{H}_{19} \mathrm{~F}_{3} \mathrm{~N}_{2} \mathrm{O}_{2} \mathrm{~S}$ (444.47): $\mathrm{C}, 62.15 ; \mathrm{H}, 4.31 ; \mathrm{N}, 6.30 ; \mathrm{S}, 7.21 \%$; Found: $\mathrm{C}, 62.29 ; \mathrm{H}$, $4.28 ; \mathrm{N}, 6.29 ; \mathrm{S} 7.30 \%$.

2-((4-Ethylphenoxy)methyl)-N-(2,4,5-trifluorophenylcarbamothioyl)benzamide (5c) $3.24 \mathrm{~g}$ white crystals (yield $73 \%$ ), mp $114-115^{\circ} \mathrm{C}$.

${ }^{1} \mathrm{H}-\mathrm{NMR}$ (DMSO-d6): 12.30 (br s, $\left.1 \mathrm{H}, \mathrm{NH}\right), 12.12$ (br s, $\left.1 \mathrm{H}, \mathrm{NH}\right), 8.07$ (ddd, ${ }^{3} J_{(\mathrm{H} 22-\mathrm{F} 18)}=7.2 \mathrm{~Hz}$, $\left.{ }^{3} J_{(\mathrm{H} 22-\mathrm{F} 20)}=8.6 \mathrm{~Hz},{ }^{3} J_{(\mathrm{H} 22-\mathrm{F} 21)}=11.7 \mathrm{~Hz}, 1 \mathrm{H}, \mathrm{H}-22\right), 7.70\left(\mathrm{td},{ }^{3} J_{(\mathrm{H} 19-\mathrm{F} 21)}=7.4 \mathrm{~Hz},{ }^{3} J_{(\mathrm{H} 19-\mathrm{F} 20,21)}=10.7\right.$ $\mathrm{Hz}, 1 \mathrm{H}, \mathrm{H}-19), 7.62(\mathrm{dd}, J=1.2 \mathrm{~Hz}, J=7.6 \mathrm{~Hz}, 1 \mathrm{H}, \mathrm{H}-7), 7.60(\mathrm{~m}, 1 \mathrm{H}, \mathrm{H}-4), 7.57(\mathrm{td}, J=1.2 \mathrm{~Hz}, J=7.6$ $\mathrm{Hz}, 1 \mathrm{H}, \mathrm{H}-5), 7.47$ (td, $J=1.4 \mathrm{~Hz}, J=7.5 \mathrm{~Hz}, 1 \mathrm{H}, \mathrm{H}-6), 7.08$ (d, $J=8.6 \mathrm{~Hz}, 2 \mathrm{H}, \mathrm{H}-11, \mathrm{H}-13), 6.89$ (d, $J=$ $8.6 \mathrm{~Hz}, 2 \mathrm{H}, \mathrm{H}-10, \mathrm{H}-14), 5.26$ (s, 2H, H-8), 2.50 (q, J = 7.5 Hz, 2H, H-15), 1.12 (t, J = 7.5 Hz, 3H, H-15') (Figure S7a,b).

${ }^{13}$ C-NMR (DMSO-d6): 181.36 (C-16), 170.27 (C-1), $156.17(\mathrm{C}-9), 151.17$ (ddd, ${ }^{4} J_{(\mathrm{C} 18-\mathrm{F})}=2.6 \mathrm{~Hz}$, $\left.{ }^{3} J_{(\mathrm{C} 18-\mathrm{F})}=9.9 \mathrm{~Hz}, J_{(\mathrm{C}-\mathrm{F})}=246.4 \mathrm{~Hz}, \mathrm{C}-18\right), 147.17\left(\mathrm{ddd}, J_{(\mathrm{C} 20-\mathrm{F})}=12.2 \mathrm{~Hz}, J_{(\mathrm{C} 20-\mathrm{F})}=14.4 \mathrm{~Hz}, J_{(\mathrm{C} 20-\mathrm{F})}=\right.$ $248.0 \mathrm{~Hz}, \mathrm{C}-20), 144.89\left(\mathrm{ddd},{ }^{4} J_{(\mathrm{C} 21-\mathrm{F} 18)}=3.7 \mathrm{~Hz},{ }^{2} J_{(\mathrm{C} 21-\mathrm{F} 20)}=13.3 \mathrm{~Hz}, J_{(\mathrm{C} 21-\mathrm{F})}=242.0 \mathrm{~Hz}, \mathrm{C}-21\right), 136.17$ (Cq), 135.82 (Cq), 133.04 (Cq), 131.06 (C-5), 128.50 (C-11, C-13), 128.49 (C-4), 128.40 (C-7), 127.71 (C-6), $122.87\left(\mathrm{ddd},{ }^{4} J_{(\mathrm{C} 17-\mathrm{F} 20)}=4.0 \mathrm{~Hz},{ }^{3} J_{(\mathrm{C} 17-\mathrm{F} 21)}=9.1 \mathrm{~Hz},{ }^{2} J_{(\mathrm{C} 17-\mathrm{F} 18)}=13.2 \mathrm{~Hz}, \mathrm{C}-17\right), 115.29\left(\mathrm{dd},{ }^{3} J_{(\mathrm{C} 22-\mathrm{F} 20)}\right.$ $\left.=2.8 \mathrm{~Hz},{ }^{2} J_{(\mathrm{C} 22-\mathrm{F} 21)}=23.5 \mathrm{~Hz}, \mathrm{C}-22\right), 114.53(\mathrm{C}-10, \mathrm{C}-14), 105.93\left(\mathrm{dd},{ }^{2} J_{(\mathrm{C} 20-\mathrm{F})}=22.1 \mathrm{~Hz},{ }^{2} J_{(\mathrm{C} 20-\mathrm{F})}=26.4\right.$ $\mathrm{Hz}, \mathrm{C}-19), 67.48$ (C-8), 27.18 (C-15), 15.68 (C-15') (Figure S7c).

${ }^{19}$ F-NMR (DMSO-d6): -118.49 (m, F-18), -131.70 (m, F-21), -137.65 (m, F-20).

FTIR (solid in ATR, $v \mathrm{~cm}^{-1}$ ): 3401w, 3269w, 3069w, 2964w, 1676m, 1602w, 1567s, 1508vs, 1439s, $1422 \mathrm{~m}, 1381 \mathrm{w}, 1317 \mathrm{~s}, 1239 \mathrm{~s}, 1216 \mathrm{~s}, 1170 \mathrm{~ms}, 1151 \mathrm{~s}, 1054 \mathrm{w}, 1036 \mathrm{w}, 882 \mathrm{w}, 869 \mathrm{w}, 834 \mathrm{w}, 752 \mathrm{w}, 737 \mathrm{w}, 680 \mathrm{w}$, $642 \mathrm{w}, 613 \mathrm{w}$. 
Anal. Calcd for $\mathrm{C}_{23} \mathrm{H}_{19} \mathrm{~F}_{3} \mathrm{~N}_{2} \mathrm{O}_{2} \mathrm{~S}$ (444.47): C, 62.15; H, 4.31; N, 6.30; S, 7.21\%; Found: C, 61.89; $\mathrm{H}$, $4.34 ; \mathrm{N}, 6.27 ; \mathrm{S} 7.26 \%$.

2-((4-Ethylphenoxy)methyl)- $N$-(2,4,6-trifluorophenylcarbamothioyl)benzamide (5d) $3.20 \mathrm{~g}$ white crystals (yield $72 \%$ ), mp $122-123^{\circ} \mathrm{C}$.

${ }^{1} \mathrm{H}-\mathrm{NMR}$ (DMSO-d6): 12.14 (br s, $\left.1 \mathrm{H}, \mathrm{NH}\right), 11.56$ (br s, $\left.1 \mathrm{H}, \mathrm{NH}\right), 7.64(\mathrm{dd}, J=1.2 \mathrm{~Hz}, J=7.6 \mathrm{~Hz}$, $1 \mathrm{H}, \mathrm{H}-7), 7.60(\mathrm{~m}, 1 \mathrm{H}, \mathrm{H}-4), 7.57(\mathrm{td}, J=1.2 \mathrm{~Hz}, J=7.6 \mathrm{~Hz}, 1 \mathrm{H}, \mathrm{H}-5), 7.47(\mathrm{td}, J=1.42 \mathrm{~Hz}, J=7.5 \mathrm{~Hz}, 1 \mathrm{H}$, H-6), 7.30 (m, 2H, H-19, H-20), 7.08 (d, J = 8.6 Hz, 2H, H-11, H-13), 6.89 (d, J = 8.6 Hz, 2H, H-10, H-14), 5.27 (s, 2H, H-8), 2.51 (q, J = 7.5 Hz, 2H, H-15), 1.14 (t, $J=7.5 \mathrm{~Hz}, 3 \mathrm{H}, \mathrm{H}-15^{\prime}$ ) (Figure S8a,b).

${ }^{13} \mathrm{C}-\mathrm{NMR}$ (DMSO-d6): $182.27(\mathrm{C}-16), 169.75(\mathrm{C}-1), 160.82\left(\mathrm{dt},{ }^{3} J_{(\mathrm{C} 20-\mathrm{F} 18,22)}=30.2 \mathrm{~Hz} J_{(\mathrm{C} 20-\mathrm{F} 20)}=\right.$ $247.1 \mathrm{~Hz}, \mathrm{C}-20), 158.15\left(\mathrm{ddd}, J_{(\mathrm{C}-\mathrm{F})}=7.3 \mathrm{~Hz}, J_{(\mathrm{C}-\mathrm{F})}=16.1 \mathrm{~Hz}, J_{(\mathrm{C}-\mathrm{F})}=250.0 \mathrm{~Hz}, \mathrm{C}-18, \mathrm{C}-22\right), 156.12$ (C-9), 136.19 (Cq), 135.86 (Cq), 132.97 (Cq), 131.04 (C-5), 128.61 (C-4), 128.51 (C-11, C-13), 128.46 (C-7), 127.68 (C-6), 114.68 C-10, C-14), $113.35\left(\mathrm{td}, J_{(\mathrm{C} 17-\mathrm{F} 20)}=5.1 \mathrm{~Hz}, J_{(\mathrm{C} 17-\mathrm{F} 18,22)}=16.5 \mathrm{~Hz}, \mathrm{C}-17\right), 100.76$ $\left(\mathrm{td}, J_{(\mathrm{C} 19,21-\mathrm{F} 20)}=3.6 \mathrm{~Hz}, J_{(\mathrm{C} 19,21-\mathrm{F} 18,22)}=27.1 \mathrm{~Hz}, \mathrm{C}-19, \mathrm{C}-21\right), 67.53(\mathrm{C}-8), 27.21(\mathrm{C}-15), 15.74\left(\mathrm{C}-15^{\prime}\right)$ (Figure S8c,d).

${ }^{19}$ F-NMR (DMSO-d6): -108.85 (m, F-20), -114.85 (m, F-18, F-22).

FTIR (solid in ATR, $v \mathrm{~cm}^{-1}$ ): 3160m, 3066m, 3009m, 2965m, 2933m, 2872m, 1683s, 1644w, 1599w, $1508 \mathrm{vs}, 1449 \mathrm{vs}, 1384 \mathrm{~m}, 1313 \mathrm{w}, 1246 \mathrm{~s}, 1222 \mathrm{~m}, 1173 \mathrm{vs}, 1126 \mathrm{~s}, 1068 \mathrm{w}, 1041 \mathrm{~s}, 1019 \mathrm{~m}, 999 \mathrm{~m}, 949 \mathrm{w}, 882 \mathrm{w}$, $838 \mathrm{~m}, 809 \mathrm{w}, 763 \mathrm{~m}, 748 \mathrm{~m}, 730 \mathrm{~m}, 660 \mathrm{~m}, 611 \mathrm{w}, 552 \mathrm{w}$.

Anal. Calcd for $\mathrm{C}_{23} \mathrm{H}_{19} \mathrm{~F}_{3} \mathrm{~N}_{2} \mathrm{O}_{2} \mathrm{~S}$ (444.47): $\mathrm{C}, 62.15 ; \mathrm{H}, 4.31 ; \mathrm{N}, 6.30 ; \mathrm{S}, 7.21 \%$; Found: $\mathrm{C}, 62.32 ; \mathrm{H}$, $4.38 ; \mathrm{N}, 6.37 ; \mathrm{S} 7.21 \%$.

2-((4-Ethylphenoxy)methyl)-N-(3,4,5-trifluorophenylcarbamothioyl)benzamide (5e) $3.33 \mathrm{~g}$ light yellow crystals (yield $75 \%$ ), mp $133-134{ }^{\circ} \mathrm{C}$.

${ }^{1} \mathrm{H}-\mathrm{NMR}$ (DMSO-d6): 12.39 (br s, 1H, NH), 12.00 (br s, 1H, NH), 7.62- 7.58 (m, 1H, H-4), 7.64 (dd, $J=1.2 \mathrm{~Hz}, J=7.6 \mathrm{~Hz}, 1 \mathrm{H}, \mathrm{H}-7), 7.57(\mathrm{td}, J=1.2 \mathrm{~Hz}, J=7.6 \mathrm{~Hz}, 1 \mathrm{H}, \mathrm{H}-5), 7.47(\mathrm{td}, J=1.4 \mathrm{~Hz}, J=7.5$ $\mathrm{Hz}, 1 \mathrm{H}, \mathrm{H}-6), 7.09$ (d, J = 8.6 Hz, 2H, H-11, H-13), 6.89 (d, J = 8.6 Hz, 2H, H-10, H-14), 5.26 (s, 2H, H-8), $2.51(\mathrm{q}, J=7.5 \mathrm{~Hz}, 2 \mathrm{H}, \mathrm{H}-15), 1.12\left(\mathrm{t}, J=7.5 \mathrm{~Hz}, 3 \mathrm{H}, \mathrm{H}-15^{\prime}\right)$ (Figure S9a).

${ }^{13}$ C-NMR (DMSO-d6): 179.60 (C-16), 169.99 (C-1), 156.24 (C-9), 146.69 (ddd, ${ }^{3} J_{(\mathrm{C} 19,21-\mathrm{F} 19,21)}=5.4$ $\left.\mathrm{Hz},{ }^{2} J_{(\mathrm{C} 19,21-\mathrm{F} 20)}=10.1 \mathrm{~Hz}, J_{(\mathrm{C} 19,21-\mathrm{F} 19,21)}=245.0 \mathrm{~Hz}, \mathrm{C}-19, \mathrm{C}-21\right), 136.73\left(\mathrm{dt}, J_{(\mathrm{C} 20-\mathrm{F} 19,21)}=15.7 \mathrm{~Hz}\right.$, $\left.J_{(\mathrm{C} 20-\mathrm{F} 20)}=248.1 \mathrm{~Hz}, \mathrm{C}-20\right), 136.17(\mathrm{Cq}), 135.87(\mathrm{Cq}), 134.06\left(\mathrm{td}, J_{(\mathrm{C} 17-\mathrm{F} 20)}=4.0 \mathrm{~Hz}, J_{(\mathrm{C} 17-\mathrm{F} 19,21)}=11.5\right.$ Hz, C-17), 133.11(Cq), 131.07 (C-5), 128.54 (C-11, C-13), 128.41 (C-4), 128.35 (C-7), 127.71 (C-6), 114.49 $(\mathrm{C}-10, \mathrm{C}-14), 109.60\left(\mathrm{~m},{ }^{3} J_{(\mathrm{C} 18,22-\mathrm{F} 20)}=6.5 \mathrm{~Hz},{ }^{2} J_{(\mathrm{C} 18,22-\mathrm{F} 19,21)}=23.4 \mathrm{~Hz}, \mathrm{C}-18, \mathrm{C}-22\right), 67.42(\mathrm{C}-8), 27.19$ (C-15), 15.66 (C-15') (Figure S9b,c).

${ }^{19} \mathrm{~F}-\mathrm{NMR}(\mathrm{DMSO}-\mathrm{d} 6):-130.84\left(\mathrm{dd},{ }^{2} J_{(\mathrm{H} 18,22-\mathrm{F} 19,21)}=9.8 \mathrm{~Hz},{ }^{3} J_{(\mathrm{F} 20-\mathrm{F} 19,21)}=22.4 \mathrm{~Hz}, \mathrm{~F}-19, \mathrm{~F}-21\right)$, $-159.53\left(\mathrm{tt}^{4} J_{(\mathrm{F} 20-\mathrm{H} 18,22)}=6.3 \mathrm{~Hz},{ }^{3} J_{(\mathrm{F} 19,21-\mathrm{F} 20)}=22.4 \mathrm{~Hz}, \mathrm{~F}-20\right)$.

FTIR (solid in ATR, $v \mathrm{~cm}^{-1}$ ): $3174 \mathrm{~m}, 3038 \mathrm{~m}, 2965 \mathrm{~m}, 2879 \mathrm{~m}, 2843 \mathrm{w}, 1689 \mathrm{~m}, 1626 \mathrm{w}, 1609 \mathrm{~m}, 1582 \mathrm{w}$, $1554 \mathrm{~m}, 1510 \mathrm{vs}, 1441 \mathrm{~s}, 1368 \mathrm{~m}, 1305 \mathrm{~m}, 1252 \mathrm{~m}, 1237 \mathrm{~s}, 1211 \mathrm{~s}, 1178 \mathrm{vs}, 1142 \mathrm{~s}, 1079 \mathrm{w}, 1047 \mathrm{~s}, 1015 \mathrm{~m}, 864 \mathrm{w}$, $850 \mathrm{w}, 832 \mathrm{~m}, 820 \mathrm{w}, 753 \mathrm{~m}, 715 \mathrm{~m}, 654 \mathrm{w}, 591 \mathrm{w}$.

Anal. Calcd for $\mathrm{C}_{23} \mathrm{H}_{19} \mathrm{~F}_{3} \mathrm{~N}_{2} \mathrm{O}_{2} \mathrm{~S}$ (444.47): C, 62.15; H, 4.31; N, 6.30; $\mathrm{S}, 7.21 \%$; Found: $\mathrm{C}, 62.34 ; \mathrm{H}$, $4.37 ; \mathrm{N}, 6.21 ; \mathrm{S} 7.15 \%$.

2-((4-Ethylphenoxy)methyl)-N-(2-trifluoromethylphenylcarbamothioyl)benzamide (5f) $3.39 \mathrm{~g}$ white crystals (yield $74 \%$ ); mp $123-124{ }^{\circ} \mathrm{C}$.

${ }^{1} \mathrm{H}-\mathrm{NMR}$ (DMSO-d6): 12.44 (br s, 1H, NH), 12.14 (br s, $\left.1 \mathrm{H}, \mathrm{NH}\right), 7.79$ (dq, ${ }^{4} J_{(3 \mathrm{~F}-\mathrm{H} 19)}=0.9 \mathrm{~Hz}$, $\left.J_{(\mathrm{H} 19-\mathrm{H} 20)}=8.4 \mathrm{~Hz}, 1 \mathrm{H}, \mathrm{H}-19\right), 7.76-7.70(\mathrm{~m}, 2 \mathrm{H}, \mathrm{H}-21, \mathrm{H}-22), 7.63(\mathrm{dd}, J=1.2 \mathrm{~Hz}, J=7.6 \mathrm{~Hz}, 1 \mathrm{H}, \mathrm{H}-7)$, $7.61(\mathrm{~m}, 1 \mathrm{H}, \mathrm{H}-4), 7.57(\mathrm{td}, J=1.2 \mathrm{~Hz}, J=7.6 \mathrm{~Hz}, 1 \mathrm{H}, \mathrm{H}-5), 7.53(\mathrm{~m}, 1 \mathrm{H}, \mathrm{H}-20), 7.47(\mathrm{td}, J=1.4 \mathrm{~Hz}, J=$ $7.5 \mathrm{~Hz}, 1 \mathrm{H}, \mathrm{H}-6), 7.09$ (d, J = 8.6 Hz, 2H, H-11, H-13), 6.89 (d, J = 8.6 Hz, 2H, H-10, H-14), 5.27 (s, 2H, $\mathrm{H}-8), 2.52(\mathrm{q}, J=7.5 \mathrm{~Hz}, 2 \mathrm{H}, \mathrm{H}-15), 1.13\left(\mathrm{t}, J=7.5 \mathrm{~Hz}, 3 \mathrm{H}, \mathrm{H}-15^{\prime}\right)$ (Figure S10a,b). 
${ }^{13}$ C-NMR (DMSO-d6): 181.39 (C-16), 170.61 (C-1), 156.16 (C-9), 136.17 (Cq), 135.77 (Cq), 135.69 $\left(\mathrm{q},{ }^{3} J_{(3 \mathrm{~F}-\mathrm{C} 17)}=2.2 \mathrm{~Hz}, \mathrm{C}-17\right), 133.08(\mathrm{Cq}), 132.62(\mathrm{C}-22), 131.08$ (C-5), $130.56(\mathrm{C}-20), 128.5$ 3(C-11, C-13), 128.49 (C-4), 127.76 (C-7), $127.62(\mathrm{C}-6), 126.09$ (q, $\left.{ }^{3} J_{(3 \mathrm{~F}-\mathrm{C} 20)}=5.2 \mathrm{~Hz}, \mathrm{C}-19\right), 124.41\left(\mathrm{q}, J_{(3 \mathrm{~F}-\mathrm{C} 18)}=29.3 \mathrm{~Hz}\right.$, $\mathrm{C}-18), 123.30\left(\mathrm{q}, J_{(3 \mathrm{~F}-\mathrm{C})}=271.7 \mathrm{~Hz}, \mathrm{CF}_{3}\right), 114.51(\mathrm{C}-10, \mathrm{C}-14), 67.43(\mathrm{C}-8), 27.22(\mathrm{C}-15), 15.73\left(\mathrm{C}-15^{\prime}\right)$ (Figure S10c,d).

${ }^{19}$ F-NMR (DMSO-d6): $-55.64(3 \mathrm{~F})$.

FTIR (solid in ATR, $v \mathrm{~cm}^{-1}$ ):3176s, 3011m, 2972m, 2912m, 2870w, 1695m, 1608m, 1586m, 1508vs, $1471 \mathrm{~m}, 1455 \mathrm{~m}, 1374 \mathrm{w}, 1318 \mathrm{~s}, 1284 \mathrm{~m}, 1250 \mathrm{~s}, 1230 \mathrm{~s}, 1156 \mathrm{vs}, 1135 \mathrm{~s}, 1107 \mathrm{~s}, 1076 \mathrm{~m}, 1059 \mathrm{~m}, 1025 \mathrm{~s}, 890 \mathrm{w}$, $871 \mathrm{w}, 824 \mathrm{~m}, 801 \mathrm{w}, 777 \mathrm{~m}, 756 \mathrm{~s}, 735 \mathrm{~m}, 716 \mathrm{w}, 688 \mathrm{w}, 664 \mathrm{w}, 650 \mathrm{w}, 638 \mathrm{w}, 610 \mathrm{w}$.

Anal. Calcd for $\mathrm{C}_{24} \mathrm{H}_{21} \mathrm{~F}_{3} \mathrm{~N}_{2} \mathrm{O}_{2} \mathrm{~S}$ (458.49): C, 62.87; H, 4.62; N, 6.11; S, 6.99\%; Found: C, 62.98; $\mathrm{H}$, $4.58 ; \mathrm{N}, 6.23 ; \mathrm{S} 7.04 \%$.

2-((4-Ethylphenoxy)methyl)-N-(4-trifluoromethylphenylcarbamothioyl)benzamide (5g) $3.25 \mathrm{~g}$ light yellow crystals (yield $71 \%$ ), mp $138-139{ }^{\circ} \mathrm{C}$.

${ }^{1} \mathrm{H}-\mathrm{NMR}$ (DMSO-d6): 12.59 (br s, 1H, NH), 11.96 (br s, 1H, NH), 7.88 (d, J = 8.4 Hz, 2H, H-19, H-21), $7.76(\mathrm{~d}, J=8.4 \mathrm{~Hz}, 2 \mathrm{H}, \mathrm{H}-18, \mathrm{H}-22), 7.63(\mathrm{dd}, J=1.4 \mathrm{~Hz}, J=7.2 \mathrm{~Hz}, 1 \mathrm{H}, \mathrm{H}-7), 7.60(\mathrm{dd}, J=1.7 \mathrm{~Hz}$, $J=7.8 \mathrm{~Hz}, 1 \mathrm{H}, \mathrm{H}-4), 7.57(\mathrm{td}, J=1.4 \mathrm{~Hz}, J=7.62 \mathrm{~Hz}, 1 \mathrm{H}, \mathrm{H}-5), 7.47(\mathrm{td}, J=1.7 \mathrm{~Hz}, J=7.5 \mathrm{~Hz}, 1 \mathrm{H}, \mathrm{H}-6)$, 7.07 (d, J = 8.6 Hz, 2H, H-11, H-13), 6.89 (d, J = 8.6 Hz, 2H, H-10, H-14), 5.28 (s, 2H, H-8), 2.50 (q, J = 7.5 $\mathrm{Hz}, 2 \mathrm{H}, \mathrm{H}-15), 1.10\left(\mathrm{t}, \mathrm{J}=7.5 \mathrm{~Hz}, 3 \mathrm{H}, \mathrm{H}-15^{\prime}\right)$ (Figure S11a,b).

${ }^{13}$ C-NMR (DMSO-d6): 178.22 (C-16), 170.07 (C-1), 156.23 (C-9), 141.48 (Cq), 131.02 (C-5), 128.54 (C-11, C-13), 128.44 (C-7), 128.30 (C-4), 127.67 (C-6), 126.10 (q, J(3F-C20) $=32.0 \mathrm{~Hz}, \mathrm{C}-20), 125.65$ (q, $\left.{ }^{3} J_{(3 \mathrm{~F}-\mathrm{C} 19,21)}=3.7 \mathrm{~Hz}, \mathrm{C}-19, \mathrm{C}-21\right), 124.02\left(\mathrm{q}, J_{(3 \mathrm{~F}-\mathrm{C})}=271.0 \mathrm{~Hz}, \mathrm{CF}_{3}\right), 124.41(\mathrm{C}-18, \mathrm{C}-22), 114.51(\mathrm{C}-10$, C-14), 67.45 (C-8), 27.18 (C-15), 15.67 (C-15') (Figure S11c,d).

${ }^{19}$ F-NMR (DMSO-d6): $-55.53(3 \mathrm{~F})$.

FTIR (solid in ATR, $v \mathrm{~cm}^{-1}$ ): 3185m, 3028m, 2959m, 2930m, 2872w, 1691s, 1601m, 1553s, 1525vs, 1510vs, 1554m, 1414w, 1392w, 1319vs, 1239s, 1159vs, 1120vs, 1106vs, 1078w, 1066vs, 1032m, 1014m, $874 \mathrm{w}, 826 \mathrm{~m}, 739 \mathrm{~m}, 713 \mathrm{~m}, 678 \mathrm{w}, 649 \mathrm{w}, 615 \mathrm{w}$.

Anal. Calcd for $\mathrm{C}_{24} \mathrm{H}_{21} \mathrm{~F}_{3} \mathrm{~N}_{2} \mathrm{O}_{2} \mathrm{~S}$ (458.49): C, 62.87; H, 4.62; N, 6.11; S, 6.99\%; Found: C, 62.68; $\mathrm{H}$, $4.68 ; \mathrm{N}, 6.24 ; \mathrm{S} 7.08 \%$.

\subsubsection{Single Crystal X-ray Diffraction, Crystal Data Collection and Refinement}

A colorless block crystal of $\mathrm{C}_{23} \mathrm{H}_{19} \mathrm{~F}_{3} \mathrm{~N}_{2} \mathrm{O}_{2} \mathrm{~S}$ with approximate size of $0.400 \times 0.350 \times 0.200 \mathrm{~mm}$ was measured with a Rigaku R-AXIS RAPID II diffractometer using graphite monochromated Mo-K $\alpha$ radiation. The data were collected at a temperature of $20 \pm 1^{\circ} \mathrm{C}$ to a maximum $2 \theta$ value of $55.0^{\circ}$. Of the 15,071 reflections that were collected, 4927 were unique $\left(R_{\text {int }}=0.0251\right)$. The linear absorption coefficient, $\mu$, for $\mathrm{Mo}-\mathrm{K}_{\alpha}$ radiation is $1.983 \mathrm{~cm}^{-1}$. The data were corrected for Lorentz and polarization effects. The structure was solved by direct methods [54] and expanded using Fourier techniques. Refinement of $\mathrm{F}^{2}$ was done against all reflections. The weighted $\mathrm{R}$ factor, $\mathrm{w} \mathrm{R}$, and goodness of fit are based on $\mathrm{F}^{2}$. The non-hydrogen atoms were refined anisotropically. Hydrogen atoms were refined using the riding model. All calculations were performed using the CrystalStructure [56] crystallographic software package except for refinement, which was performed using SHELXL97 [57]. Crystallographic data were submitted to the Cambridge Structural Data Base with the deposition number 1965014.

\subsection{Computational Analyses}

The ligands were prepared using SPARTAN'14 software package [Spartan'14 Wavefunction, Inc. Irvine, CA]. The DFT/B3LYP/6-31 G* level of basis set was used for the computation of molecular structure, vibrational frequencies, and energies of optimized structures. Molecular docking approach using CLC Drug Discovery Workbench Software was conducted.

All investigated compounds were virtually docked against E. coli DNA gyrase B, which was downloaded from the Protein Data Bank (PDB ID: 4DUH) [58]. 
The steps to go through to explore protein-ligand interaction are: Set up the binding site in a molecule project, dock the ligands imported to a molecule table, and inspect the docking results.

\subsection{In Vitro Assessment of the Antimicrobial Activity of the Newly Synthesized F-Benzoylthiourea Derivatives on Planktonic Microbes (Grown in Suspension)}

The inhibitory activity upon microbial growth was tested on Gram-positive (S. aureus ATCC 25923, E. faecalis ATCC 29212, B. subtilis ATCC 6633) and Gram-negative (E. coli ATCC 25922, P. aeruginosa ATCC 27853) bacteria and one fungal (C. albicans ATCC 10231) strain. The compounds were solubilized in DMSO to a final concentration of $10 \mathrm{mg} / \mathrm{mL}$ and further sterilized by filtration (using $0.22 \mu \mathrm{m}$ filter membranes). The quantitative assay of the minimal inhibitory concentration (MIC, $\mu \mathrm{g} / \mathrm{mL}$ ) was performed by the microdilution method in 96 multi-well plates [59]. In this purpose, serial binary dilutions (ranging between 1024 and $8 \mu \mathrm{g} / \mathrm{mL}$ ) were achieved in nutrient broth/YPG (yeast peptone glucose) and each well was seeded with microbial inoculum of $0.5 \mathrm{McF}$ arland density. The plates were incubated for 24 hours at $37^{\circ} \mathrm{C}$ in the case of bacterial strains, and 48 hours at $28^{\circ} \mathrm{C}$ in the case of the fungal strain. The respective MIC values were reported as being the lowest concentration of the tested compound which inhibited the visible microbial growth.

\subsection{Antimicrobial Activity of Newly Synthesized F-Benzoylthiourea Derivatives on Microbial Adherence and Biofilms' Development on the Inert Substratum}

The antibiofilm activity was assessed by the microtiter method. For this purpose, after reading the MIC, the microplates were emptied and the microbial biofilms formed on the plastic walls were fixed with cold methanol, stained with $1 \%$ violet crystal solution, and resuspended in $30 \%$ acetic acid. The absorbance of the colored suspension was measured at $490 \mathrm{~nm}$ with an ELISA reader (Apollo LB 911). The inhibition of the microbial biofilm development was interpreted as the decrease of the absorbance below the value registered for the positive control [60-64].

\section{Conclusions}

We report here the synthesis, characterization, and bioevaluation of new fluorinated compounds as potential antimicrobials. The antibacterial and antifungal activity was correlated with the position of fluorine or trifluoromethyl substituents on the phenyl ring. The molecular docking simulation was performed to predict the binding modes of the obtained benzoylthiourea derivatives to $E$. coli DNA gyrase B (chosen because E. coli strain was the most susceptible to the highest number of the tested compounds), the binding affinities, and the orientation. The docking score, predicting the antimicrobial activity of the studied compounds, was correlated with the experimental data obtained from the evaluation of the antimicrobial activity against the E. coli strain.

Supplementary Materials: The following are available online at http://www.mdpi.com/1420-3049/25/7/1478/s1, Figure S1. Packing diagram of the crystal structure of $\mathbf{5 d}$ along a axis. Figure S2. Packing diagram of the crystal structure of $\mathbf{5 d}$ along $\mathrm{b}$ axis. Figure S3. Packing diagram of the crystal structure of $\mathbf{5 d}$ along c axis. Figure S4. Molecular docking studies with 4DUH receptor, Figure S5a-g. The NMR spectra of 2-((4-Ethylphenoxy)methyl)-N-(3-fluorophenylcarbamothioyl)benzamide (5a), Figure S6a-g. The NMR spectra of 2-((4-Ethylphenoxy)methyl)-N-(2,3,4-trifluorophenylcarbamothioyl)benzamide (5b), Figure S7a-f. The NMR spectra of 2-((4-Ethylphenoxy)methyl)-N-(2,4,5-trifluorophenylcarbamothioyl)benzamide (5c), Figure S8a-e. The NMR spectra of 2-((4-Ethylphenoxy)methyl)-N-(2,4,6-trifluorophenylcarbamothioyl)benzamide (5d), Figure S9a-f. The NMR spectra of 2-((4-Ethylphenoxy)methyl)-N-(3,4,5-trifluorophenylcarbamothioyl)benzamide (5e), Figure S10a-g. The NMR spectra of 2-((4-Ethylphenoxy)methyl)-N-(2-trifluoromethylphenylcarbamothioyl)benzamide (5f), Figure S11a-f. The NMR spectra of 2-((4-Ethylphenoxy)methyl)-N-(4-trifluoromethylphenylcarbamothioyl)benzamide (5g), Table S1. Crystallographic data for 5d, Table S2. Selected bond lengths $(\AA \AA)$ for $5 \mathrm{~d}$, Table S3. Selected bond lengths $(\AA)$ and angles $\left({ }^{\circ}\right)$ for $\mathbf{5 d}$, Table S4. Selected bond lengths $(\AA)$ for $\mathbf{5 d}$, Table S5. Selected angles (o) for 5d. Table S6. Experimental and theoretical 1H-, 13C- and 19F correlation NMR for 5d, Table S7. The list of intermolecular interactions between the ligand molecules docked with 4DUH (E. coli DNA gyrase B) using CLC Drug Discovery Workbench Software. 
Author Contributions: Conceptualization, C.L., D.C.N. and I.M.V.; methodology, L.G.M., M.C.C., M.T.C., F.D., C.B. and C.L.; software, M.F., L.P. and A.S.; validation, C.L.; writing-original draft preparation, C.L.; writing-review and editing, C.L. and D.C.N.; visualization, M.C.C.; supervision, C.L. All authors have contributed substantially to the work reported. All authors have read and agreed to the published version of the manuscript.

Funding: We gratefully acknowledge the financial support of UEFISCDI research projects PN-III-P4-ID-PCCF-2016-0114 (RADAR) and 52 PCCDI.

Conflicts of Interest: The authors declare no conflict of interest

\section{References}

1. Vedavathia, P.; Sekhara, C.K.; Rajua, N.C. Synthesis, spectral characterization and antimicrobial activity of thiourea/urea derivatives of amlodipine. Pharm. Lett. 2013, 5, 199-204.

2. Reddy, V.R.; Raju, N.; Reddy, C.K.; Rao, S. Urea and thiourea derivatives of celecoxib drug: Synthesis and evaluation of antimicrobial activity. IAJPR 2013, 3, 8228-8236.

3. Mannam, M.R.; Devineni, S.R.; Pavuluri, C.M.; Chamarthi, N.R.; Pal, M. Urea and thiourea derivatives of 3-(trifluoromethyl)-5,6,7,8-tetrahydro-[1,2,4]triazolo[4,3-a]pyrazine: Synthesis, characterization, antimicrobial activity and docking studies. Phosphorus, Sulfur, Silicon Relat. Elements 2019, 194, 922-932. [CrossRef]

4. Kurt, G.; Sevgi, F.; Mercimek, B. Synthesis, characterization, and antimicrobial activity of new benzoylthiourea ligands. Chem. Pap. 2009, 63, 548-553. [CrossRef]

5. Thakar, K.; Paghdar, D.; Chovatia, P.; Joshi, H.S. Synthesis of thiourea derivatives bearing the benzo[b]thiophene nucleus as potential antimicrobial agents. J. Serbian Chem. Soc. 2005, 70, 807-815. [CrossRef]

6. Semwal, A.; Nigam, A.; Gupta, S. Synthesis, characterization and biological evaluation of novel N-p-methylbenzoyl-N'substituted thiourea. AJPLS 2011, 1, 149-155.

7. Pradhan, A.; Khan, N.; Goyal, H. Antifungal and anti-bacterial Activity of neoteric substituted thiocarbamide. Int. J. Theor. Appl. Sci. 2016, 8, 41-44.

8. Ghorab, M.M.; El-Gaby, M.; Soliman, A.M.; Alsaid, M.S.; Abdel-Aziz, M.M.; Elaasser, M. Synthesis, docking study and biological evaluation of some new thiourea derivatives bearing benzenesulfonamide moiety. Chem. Cent. J. 2017, 11, 42. [CrossRef]

9. Krajačić, M.B.; Perić, M.; Smith, K.S.; Schönfeld, Z.I.; Žiher, D.; Fajdetić, A.; Kujundžić, N.; Schönfeld, W.; Landek, G.; Padovan, J.; et al. Synthesis, Structure-Activity Relationship, and Antimalarial Activity of Ureas and Thioureas of 15-Membered Azalides. J. Med. Chem. 2011, 54, 3595-3605. [CrossRef]

10. El Bissati, K.; Redel, H.; Ting, L.-M.; Lykins, J.D.; McPhillie, M.J.; Upadhya, R.; Woster, P.M.; Yarlett, N.; Kim, K.; Weiss, L.M. Novel Synthetic Polyamines Have Potent Antimalarial Activities in vitro and in vivo by Decreasing Intracellular Spermidine and Spermine Concentrations. Front. Microbiol. 2019, 9, 9. [CrossRef]

11. Mahajan, A.; Yeh, S.; Nell, M.; Van Rensburg, C.E.; Chibale, K.; Van Rensburg, C.E.J. Synthesis of new 7-chloroquinolinyl thioureas and their biological investigation as potential antimalarial and anticancer agents. Bioorganic Med. Chem. Lett. 2007, 17, 5683-5685. [CrossRef]

12. Díaz, M.; De Lucio, H.; Moreno, E.; Espuelas, S.; Aydillo, C.; Jimenez-Ruiz, A.; Ángel Toro, M.; Gutiérrez, K.J.; Martinez_Merino, V.; Cornejo, A.; et al. Synthesis and Leishmanicidal Activity of Novel Urea, Thiourea, and Selenourea Derivatives of Diselenides. Antimicrob. Agents Chemother. 2019. [CrossRef]

13. Elkholy, S.S.; Salem, H.A.; Eweis, M.; Elsabee, M.Z. Synthesis and characterization of some acyl thiourea derivatives of chitosan and their biocidal activities. Int. J. Boil. Macromol. 2014, 70, 199-207. [CrossRef]

14. Kocyigit-Kaymakcioglu, B.; Celen, A.O.; Tabanca, N.; Ali, A.; Khan, S.; Khan, I.; Wedge, D. Synthesis and Biological Activity of Substituted Urea and Thiourea Derivatives Containing 1,2,4-Triazole Moieties. Molecules 2013, 18, 3562-3576. [CrossRef]

15. Wang,H.; Zhai, Z.-W.; Shi, Y.-X.; Tan, C.-X.; Weng, J.-Q.; Han, L.; Li, B.-J.; Liu, X. Novel Trifluoromethylpyrazole Acyl Thiourea Derivatives: Synthesis, Antifungal Activity and Docking Study. Lett. Drug Des. Discov. 2019, 16, 785-791. [CrossRef]

16. Saeed, S.; Rashid, N.; Ali, M.; Hussain, R.; Jones, P.G. Synthesis, spectroscopic characterization, crystal structure and pharmacological properties of some novel thiophene-thiourea core derivatives. Eur. J. Chem. 2010, 1, 221-227. [CrossRef] 
17. Wu, J.; Shi, Q.; Chen, Z.; He, M.; Jin, L.; Hu, D. Synthesis and Bioactivity of Pyrazole Acyl Thiourea Derivatives. Molecules 2012, 17, 5139-5150. [CrossRef]

18. Ravichandran, V.; Shalini, S.; Kumar, K.S.; Rajak, H.; Agrawal, R.K. Design, Synthesis and Evaluation of Thiourea Derivatives as Antimicrobial and Antiviral Agents. Lett. Drug Des. Discov. 2019, 16, 618-624. [CrossRef]

19. Uckun, F.M.; Venkatachalam, T.K. Adamantyl thiazole thioureas. US Patent 6,960,606, 1 November 2005.

20. Küçükgüzel, I.; Tatar, E.; Küçükgüzel, S.G.; Rollas, S.; De De Clercq, E. Synthesis of some novel thiourea derivatives obtained from 5-[(4-aminophenoxy)methyl]-4-alkyl/aryl-2,4-dihydro-3H-1,2,4-triazole-3-thiones and evaluation as antiviral/anti-HIV and anti-tuberculosis agents. Eur. J. Med. Chem. 2008, 43, 381-392. [CrossRef]

21. Al-Masoudi, N.A. Amino acid derivatives. Part 5. Synthesis and anti-HIV activity of new sebacoyl precursor derived thioureido-amino acid and phthalimide derivatives. Arkivoc 2010, 2010, 185-195.

22. Galabov, A.S.; Galabov, B.S.; Neykova, N.A. Structure-activity relationship of diphenylthiourea antivirals. J. Med. Chem. 1980, 23, 1048-1051. [CrossRef]

23. Wyles, D.L.; Kaihara, K.A.; Schooley, R.T. Synergy of a Hepatitis C Virus (HCV) NS4A Antagonist in Combination with HCV Protease and Polymerase Inhibitors. Antimicrob. Agents Chemother. 2008, 52, 1862-1864. [CrossRef]

24. Reddy, N.S.; Rao, A.S.; Chari, M.A.; Kumar, V.R.; Jyothi, V.; Himabindu, V. Synthesis and anti-bacterial activity of urea and thiourea derivatives at C-8 alkyl chain of anacardic acid mixture isolated from a natural product cashew nutshell liquid (CNSL). Int. J. Org. Chem. 2011, 1, 167-175. [CrossRef]

25. Faidallah, H.M.; Khan, K.A.; Asiri, A.M. Synthesis and biological evaluation of new 3-trifluoromethylpyrazolessulfonyl-urea and thiourea derivatives as antidiabetic and antimicrobial agents. J. Fluor. Chem. 2011, 132, 131-137. [CrossRef]

26. Ramadas, K.; Suresh, G.; Janarthanan, N.; Masilamani, S. Antifungal activity of 1,3-disubstituted symmetrical and unsymmetrical thioureas. Pestic. Sci. 1998, 52, 145-151. [CrossRef]

27. Ke, S. Synthesis and herbicidal activity of N-(o-fluorophenoxyacetyl)thioureas derivatives and related fused heterocyclic compounds. Arkivoc 2006, 2006, 63.

28. Mei, H.; Han, J.; Fustero, S.; Medio-Simon, M.; Sedgwick, D.M.; Santi, C.; Ruzziconi, R.; Soloshonok, V.A. Fluorine-Containing Drugs Approved by the FDA in 2018. Chemistry 2019, 25, 11797-11819. [CrossRef]

29. Ma, J.-A.; Cahard, D. Update 1 of: Asymmetric Fluorination, Trifluoromethylation, and Perfluoroalkylation Reactions. Chem. Rev. 2008, 108, PR1-PR43. [CrossRef]

30. Ismail, F.M.D.; Drew, M.G.B.; Dascombe, M.J. Modulation of drug pharmacokinetics and pharmacodynamics by fluorine substitution. Chim. Oggi. 2009, 27, 18-22.

31. Filler, R.; Saha, R. Fluorine in medicinal chemistry: A century of progress and a 60-year retrospective of selected highlights. Futur. Med. Chem. 2009, 1, 777-791. [CrossRef]

32. Patel, N.; Patel, S.; Patel, J.; Patel, J.; Gorgamwala, Y. Synthesis and Antibacterial Activity of Thioureido Amide of Fluoroquinolone. Int. J. Boil. Chem. 2011, 5, 37-45. [CrossRef]

33. Pathak, A.K.; Chawla, V.; Saraf, S.K. Synthesis of 2-(6'-fluorobenzothiazol-2'-ylamino)-4,6-(disubstituted thioureido)-1,3-pyrimidine derivatives as antimicrobial agents. E-J. Chem. 2011, 8, 240-244. [CrossRef]

34. Saeed, A.; Shaheen, U.; Hameed, A.; Naqvi, S.H. Synthesis, characterization and antimicrobial activity of some new 1-(fluorobenzoyl)-3-(fluorophenyl)thioureas. J. Fluor. Chem. 2009, 130, 1028-1034. [CrossRef]

35. Rioton, S.; Pardo, D.G.; Cossy, J. Synthesis of Substituted $\alpha$-Trifluoromethyl Piperidinic Derivatives. Molecules 2017, 22, 483. [CrossRef]

36. Zhu, W.; Wang, J.; Wang, S.; Gu, Z.; Aceña, J.L.; Izawa, K.; Liu, H.; Soloshonok, V.A. Recent advances in the trifluoromethylation methodology and new CF3-containing drugs. J. Fluor. Chem. 2014, 167, 37-54. [CrossRef]

37. Commare, B.; Schmitt, E.; Aribi, F.; Panossian, A.; Vors, J.-P.; Pazenok, S.; Leroux, F. Fluoroalkyl Amino Reagents (FARs): A General Approach towards the Synthesis of Heterocyclic Compounds Bearing Emergent Fluorinated Substituents. Molecules 2017, 22, 977. [CrossRef]

38. Cybulska, K.; Perk, L.; Booij, J.; Laverman, P.; Rijpkema, M. Huntington's Disease: A Review of the Known PET Imaging Biomarkers and Targeting Radiotracers. Molecules 2020, 25, 482. [CrossRef]

39. De La Torre, B.G.; Albericio, F. The Pharmaceutical Industry in 2019. An Analysis of FDA Drug Approvals from the Perspective of Molecules. Molecules 2020, 25, 745. [CrossRef] 
40. Aslam, B.; Wang, W.; Arshad, M.I.; Khurshid, M.; Muzammil, S.; Rasool, M.H.; Nisar, M.A.; Alvi, R.F.; Aslam, M.A.; Qamar, M.U.; et al. Antibiotic resistance: A rundown of a global crisis. Infect. Drug Resist. 2018, 11, 1645-1658. [CrossRef]

41. Betts, J.W.; Hornsey, M.; La Ragione, R.M. Novel Antibacterials: Alternatives to Traditional Antibiotics. Adv. Microb. Physiol. 2018, 73, 123-169.

42. Spellberg, B.; Srinivasan, A.; Chambers, H.F. New Societal Approaches to Empowering Antibiotic Stewardship. JAMA 2016, 315, 1229-1230. [CrossRef]

43. Luepke, K.H.; Mohr, J.F. The Antibiotic Pipeline: Reviving Research and Development and Speeding Drugs to Market. Expert Rev. Anti-infective Ther. 2017, 15, 425-433. [CrossRef]

44. Limban, C.; Missir, A.V.; Chiriţă, I.C.; Niţulescu, G.M.; Ilie, C.; Căproiu, M.T. Some new 2-(4-ethyl-phenoxymethyl)benzoic acid thioureides: Synthesis and spectral characterisation. Rev.Chim. (Bucharest) 2009, 60, 657-661.

45. Limban, C.; Missir, A.V.; Chirita, I.C.; Nitulescu, G.M.; Caproiu, M.T.; Chifiriuc, M.C.; Israil, A.M. Synthesis and antimicrobial properties of new 2-((4-ethylphenoxy)methyl)benzoylthioureas. Chem. Pap. 2011, 65, 60-69. [CrossRef]

46. Saeed, A.; Rafique, H.; Mumtaz, A.; Bolte, M. Ethyl 4-[3-(2-methyl-benzo-yl)thio-ureido]benzoate. Acta Crystallogr. Sect. E Struct. Rep. Online 2009, 65. [CrossRef]

47. Li, Q.; Yang, C.-L. Synthesis and Crystal Structure of a Compound with Two Conformational Isomers: N-(2-methylbenzoyl)-N'-(4-nitrophenyl)thiourea. J. Chem. Crystallogr. 2008, 38, 927-930. [CrossRef]

48. Ghose, A.K.; Pritchett, A.; Crippen, G.M. Atomic physicochemical parameters for three dimensional structure directed quantitative structure-activity relationships III: Modeling hydrophobic interactions. J. Comput. Chem. 1988, 9, 80-90. [CrossRef]

49. Rk, G.B.D.; M., P.R.S.; Yadav, R.; Bps, D.R.G. Synthesis, Characterization, Single Crystal Structural Studies, Antibacterial Activity and DFT Investigations of 2-Chloro-5-Ethoxy-3,6-Bis(Methylamino)-1,4-Benzoquinone. Pharm. Anal. Acta 2015, 6. [CrossRef]

50. Lasri, J.; Eltayeb, N.E.; Ismail, A.I. Experimental and theoretical study of crystal and molecular structure of 1,2-di(9H-fluoren-9-ylidene)hydrazine. J. Mol. Struct. 2016, 1121, 35-45. [CrossRef]

51. Sarveswari, S.; Srikanth, A.; Murugan, N.A.; Vijayakumar, V.; Jasinski, J.P.; Beauchesne, H.C.; Jarvis, E.E. Synthesis, characterization of (3E)-1-(6-chloro-2-methyl-4-phenyl quinolin-3-Yl)-3-aryl prop-2-en-1-ones through IR, NMR, single crystal X-ray diffraction and insights into their electronic structure using DFT calculations. Spectrochim. Acta Part A: Mol. Biomol. Spectrosc. 2015, 136, 1010-1017. [CrossRef]

52. Korb, O.; Stützle, T.; Exner, T.E. Empirical Scoring Functions for Advanced Protein-Ligand Docking with PLANTS. J. Chem. Inf. Model. 2009, 49, 84-96. [CrossRef] [PubMed]

53. Lipinski, C.; Lombardo, F.; Dominy, B.W.; Feeney, P.J. Experimental and computational approaches to estimate solubility and permeability in drug discovery and development settings. Adv. Drug Deliv. Rev. 2001. [CrossRef]

54. Cheng, T.; Zhao, Y.; Li, X.; Lin, F.; Xu, Y.; Zhang, X.; Li, Y.; Wang, R.; Lai, L. Computation of Octanol-Water Partition Coefficients by Guiding an Additive Model with Knowledge. J. Chem. Inf. Model. 2007, 47, 2140-2148. [CrossRef] [PubMed]

55. Limban, C.; Marutescu, L.; Chifiriuc, M.C. Synthesis, Spectroscopic Properties and Antipathogenic Activity of New Thiourea Derivatives. Molecules 2011, 16, 7593-7607. [CrossRef]

56. Sheldrick, G.M. Foundations of crystallography. Acta Cryst. Section A 2008, 64, 112-122. [CrossRef]

57. Crystal Structure 4.2: Crystal Structure Analysis Package, Rigaku Corporation (2000-2015). Tokyo, 196-8666, Japan. Available online: https://www.rigaku.com/products/xrd?gclid=EAIaIQobChMI5_ Dh4buw6AIVk00YCh0tmw2wEAAYASAAEgIc3PD_BwE (accessed on 23 March 2020).

58. Brvar, M.; Perdih, A.; Renko, M.; Anderluh, G.; Turk, D.; Solmajer, T. Structure-Based Discovery of Substituted 4,5'-Bithiazoles as Novel DNA Gyrase Inhibitors. J. Med. Chem. 2012, 55, 6413-6426. [CrossRef]

59. Jankovic, A.; Erakovic, S.; Ristoscu, C.; Mihailescu, N.; Duta, L.M.; Visan, A.; Stan, G.; Popa, A.C.; Husanu, M.-A.; Luculescu, C.R.; et al. Structural and biological evaluation of lignin addition to simple and silver-doped hydroxyapatite thin films synthesized by matrix-assisted pulsed laser evaporation. J. Mater. Sci. Mater. Electron. 2015, 26. [CrossRef] 
60. Nuta, D.C.; Măruțescu, L.; Missir, A.V.; Morusciag, L.; Chirita, C.; Curutiu, C.; Badiceanu, C.D.; Papacocea, M.T.; Limban, C. In vitro evaluation of the antimicrobial activity of N-phenylcarbamothioyl benzamides against planktonic and adherent microbial cells. Rom. Biotechnol. Lett. 2017, 22, 13163-13169.

61. Stan, T.; Teodor, E.D.; Gatea, F.; Chifiriuc, M.C.; Lazăr, V. Antioxidant and antifungal activity of Romanian propolis. Rom. Biotechnol. Lett. 2017, 22, 13116-13124.

62. Bădiceanu, C.D.; Missir, A.V.; Chifiriuc, M.C.; Dracea, O.; Raut, I.; Larion, C.; Ditu, L.M.; Mihaescu, G. Antimicrobial activity of some new 2-thiophene carboxylic acid thioureides. Rom. Biotechnol. Lett. 2010, 15, 5545-5551.

63. Mihaiescu, D.E.; Cristescu, R.; Dorcioman, G.; Popescu, C.E.; Nita, C.; Socol, G.; Mihailescu, I.N.; Grumezescu, A.M.; Tamas, D.; Enculescu, M.; et al. Functionalized magnetite silica thin films fabricated by MAPLE with antibiofilm properties. Biofabrication 2013. [CrossRef] [PubMed]

64. Ciobanu, C.S.; Groza, A.; Iconaru, S.L.; Popa, C.L.; Chapon, P.; Chifiriuc, M.C.; Hristu, R.; Stanciu, G.A.; Negrila, C.C.; Ghita, R.V.; et al. Antimicrobial activity evaluation on silver doped hydroxyapatite/polydimethylsiloxane composite layer. BioMed Res. Int. 2015. [CrossRef] [PubMed]

Sample Availability: Samples of the compounds $\mathbf{5 a - g}$ are available from the authors. 